\title{
The Atomic-Level Structure of Cementitious Calcium Aluminate Silicate Hydrate
}

\author{
Aslam Kunhi Mohamed,* Pinelopi Moutzouri, Pierrick Berruyer, Brennan J. Walder, Jirawan Siramanont, \\ Maya Harris, Mattia Negroni, Sandra C. Galmarini, Stephen C. Parker, Karen L. Scrivener, \\ Lyndon Emsley,* and Paul Bowen
}

Cite This: J. Am. Chem. Soc. 2020, 142, 11060-11071

Read Online

ACCESS | 네 Metrics \& More | 回 Article Recommendations | sl Supporting Information

ABSTRACT: Despite use of blended cements containing significant amounts of aluminum for over 30 years, the structural nature of aluminum in the main hydration product, calcium aluminate silicate hydrate (C-A-S-H), remains elusive. Using first-principles calculations, we predict that aluminum is incorporated into the bridging sites of the linear silicate chains and that at high $\mathrm{Ca}: \mathrm{Si}$ and $\mathrm{H}_{2} \mathrm{O}$ ratios, the stable coordination number of aluminum is six. Specifically, we predict that silicate-bridging $\left[\mathrm{AlO}_{2}(\mathrm{OH})_{4}\right]^{5-}$ complexes are favored, stabilized by hydroxyl ligands and charge balancing calcium ions in the interlayer space. This structure is then confirmed experimentally by one- and two-dimensional dynamic nuclear polarization enhanced ${ }^{27} \mathrm{Al}$ and ${ }^{29} \mathrm{Si}$ solid-state $\mathrm{NMR}$ experiments. We notably assign a narrow ${ }^{27} \mathrm{Al} \mathrm{NMR}$ signal at $5 \mathrm{ppm}$ to the silicate-bridging $\left[\mathrm{AlO}_{2}(\mathrm{OH})_{4}\right]^{5-}$

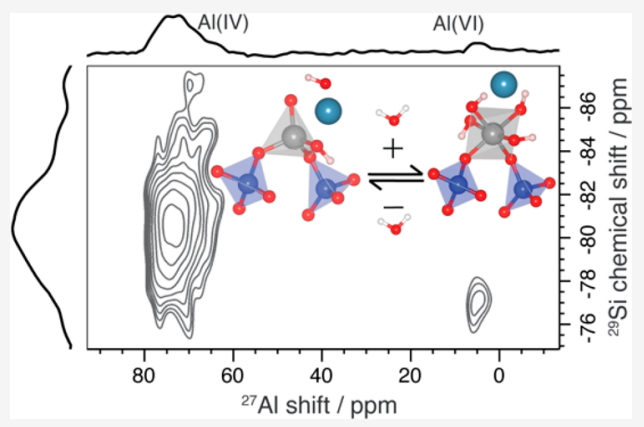
sites and show that this signal correlates to ${ }^{29} \mathrm{Si}$ NMR signals from silicates in C-A-

$\mathrm{S}-\mathrm{H}$, conflicting with its conventional assignment to a "third aluminate hydrate" (TAH) phase. We therefore conclude that TAH does not exist. This resolves a long-standing dilemma about the location and nature of the six-fold-coordinated aluminum observed by ${ }^{27} \mathrm{Al} \mathrm{NMR}$ in C-A-S-H samples.

\section{INTRODUCTION}

The most promising route toward concrete with a lower carbon footprint is by the partial substitution of Portland cement with supplementary cementitious materials (SCMs) such as fly ash, limestone, blast furnace slag, and calcined clays. ${ }^{1-5}$ Many of these SCMs are aluminum rich, and the main hydration product of such blended cements is calcium aluminate silicate hydrate (C-A-S-H), a calcium silicate hydrate $(\mathrm{C}-\mathrm{S}-\mathrm{H})^{6,7}$ that incorporates aluminum into its structure, normally with an atomic ratio of $\mathrm{Al}: \mathrm{Si} \leq 0.25$. C-S-H is a chemically disordered phase ${ }^{7-10}$ that constitutes about $50 \%$ of bulk cement by weight. ${ }^{11}$ Consequently, C-(A)-S-H is the most abundant man-made material, produced annually in quantities around 2 gigatons, as calculated for 2018 cement production. $^{12}$

The main drawback of the addition of SCMs is a general reduction in reactivity, consequently increasing the setting time of concrete and a loss of workability. Though the effects of SCMs on cement hydration have been studied extensively, ${ }^{13-16}$ questions remain regarding the atomic-level nature of the key structural phase that is produced during blended cement hydration. In the absence of SCMs, it is known that the hydration of ordinary Portland cement produces C-S-H with a variable stoichiometry, with an average $\mathrm{Ca}: \mathrm{Si}$ ratio of around 1.7 and $\mathrm{H}_{2} \mathrm{O}$ :Si ratio of around 1.8. ${ }^{17,18} \mathrm{C}-\mathrm{S}-\mathrm{H}$ has a layered calcium silicate sheet structure ( $\mathrm{Ca}-\mathrm{O}$ main layer and linear silicate chains) similar to the mineral tobermorite with a disordered interlayer space containing water molecules, calcium ions, and hydroxyl groups. ${ }^{7,19-21}$ The nature of the silicate species forming the chains and their connectivity is well-studied. ${ }^{20,22-24}$ A defective tobermorite structure can be used to represent the atomic-level features of C-SH. ${ }^{9,20,21,25-29}$ There are three types of silicate species in C-S$\mathrm{H}$ : chain-terminating tetrahedra, pairing tetrahedra, and interlayer-protruding bridging tetrahedra. The interlayer is composed of calcium as $\mathrm{Ca}^{2+}$ or $\mathrm{CaOH}^{+}$ions or $\mathrm{Ca}(\mathrm{OH})_{2}$ units, and water molecules. ${ }^{7,29}$ It has recently been shown that the bridging silicate tetrahedra can be substituted by a calcium ion, particularly at $\mathrm{Ca}: \mathrm{Si}$ ratios higher than 1.25 . $^{20}$

Solid-state ${ }^{27} \mathrm{Al}$ NMR identifies three types of aluminates in C-A-S-H samples: four-coordinate $\mathrm{Al}(\mathrm{IV})$, five-coordinate $\mathrm{Al}(\mathrm{V})$, and six-coordinate $\mathrm{Al}(\mathrm{VI})$ species. ${ }^{30-32}$ The substitution of bridging-type silicate species by $\mathrm{Al}(\mathrm{IV})$ species, particularly at low $\mathrm{Ca}: \mathrm{Si}$ ratios, is well-established. ${ }^{30,32-36}$ $\mathrm{Al}(\mathrm{V})$ is believed to exist in the interlayer, and charge

Received: March 17, 2020

Published: May 14, 2020 
compensates the incorporation of four-coordinate aluminate in the silicate chain ${ }^{30-32,37,38}$ or associates with the C-A-S-H surface. $^{39} \mathrm{Al}(\mathrm{VI})$ associated with the C-A-S-H phase can be observed in ${ }^{27} \mathrm{Al} \mathrm{NMR}$ as a particularly prominent and narrow signal around $5 \mathrm{ppm}$ when the $\mathrm{Ca}: \mathrm{Si}$ ratio is 1.0 or greater. $^{30-32,38,40}$ The proportion of $\mathrm{Al}(\mathrm{VI})$ increases with increasing $\mathrm{Ca}: \mathrm{Si}$ ratio ${ }^{40-42}$ and becomes the dominant species when the Ca:Si ratio exceeds 1.5, which is the typical case of cement hydration. ${ }^{37,40,43}$ Six-coordinate aluminates possess octahedral geometry, and in the work by Faucon et al., ${ }^{30}$ where the $5 \mathrm{ppm}$ signal was first reported, it was proposed that such species substitute for $\mathrm{Ca}^{2+}$ into the main $\mathrm{CaO}$ layer of C-S-H. This assignment, however, was called into question by Andersen and co-workers. Their $\left\{{ }^{1} \mathrm{H}\right\}^{27} \mathrm{Al}$ cross-polarization magic-angle-spinning (CP MAS) NMR experiments suggested that $\mathrm{Al}(\mathrm{VI})$ occurs as $\mathrm{AlO}_{x}(\mathrm{OH})_{6-x}(3+x)-$ species. ${ }^{31,32}$ With the observation that the $5 \mathrm{ppm}{ }^{27} \mathrm{Al}$ NMR signal is lost at elevated temperatures $\left(>70{ }^{\circ} \mathrm{C}\right)$ while the silicate framework structure is unperturbed, they concluded that this signal does not correspond to an $\mathrm{Al}(\mathrm{VI})$ species within the C-S-H. ${ }^{32}$ Instead, it was assigned to a different phase, the so-called "third aluminate hydrate" (TAH), composed of a chemically disordered aluminum hydroxide or calcium aluminate hydrate. ${ }^{31,32}$ This TAH phase was expected to exist either independently of or on the surface of C-A-S-H, with later studies suggesting penetration into the interlayer region, ${ }^{41}$ or as interlayer calcium substituted aluminate. ${ }^{44}$ Nevertheless, these findings have not been corroborated, as no method aside from solidstate ${ }^{27} \mathrm{Al}$ NMR has been able to definitively identify the TAH phase. The inability to characterize TAH further has been a hurdle in improving our understanding of how the addition of aluminates modifies cement properties.

Here, we determine the atomic-level structure of C-A-S-H and re-examine the nature of $\mathrm{Al}(\mathrm{VI})$ incorporation into $\mathrm{C}-\mathrm{S}-\mathrm{H}$, using a combination of theoretical and experimental NMR. We extend the brick model, recently developed as an atomic-level model of C-S-H, to build atomic-level C-A-S-H structural units. $^{29}$ Our results lead us to infer that $\mathrm{Al}(\mathrm{V})$ and $\mathrm{Al}(\mathrm{VI})$ aluminates can be stable species within C-A-S-H at high Ca:Si ratios when the substitution occurs at a bridging silicate site. Experimental evidence for the stability of these species in C-A$\mathrm{S}-\mathrm{H}$ is obtained with dynamic nuclear polarization (DNP)enhanced solid-state MAS NMR spectroscopy. DNP is a hyperpolarization approach for solid-state NMR that significantly enhances the NMR signal intensity by transferring high electron spin polarization from unpaired electrons (typically stable organic radicals added exogenously to the target material) to nuclei upon microwave irradiation. ${ }^{45-48}$ DNP has proven to be very effective in aiding detailed characterization of silicates, ${ }^{49-55}$ aluminosilicates, ${ }^{56-59}$ and cementitious materials. ${ }^{20,52,60,61}$ Here the sensitivity provided by DNP allows us to perform one- and two-dimensional $\left\{{ }^{29} \mathrm{Si}\right\}{ }^{27} \mathrm{Al}$ correlation NMR experiments. Correlations between resolved ${ }^{29} \mathrm{Si}$ and ${ }^{27} \mathrm{Al}$ chemical shifts give valuable structural information and demonstrate that the $\mathrm{Al}(\mathrm{VI})$ signal at 5 ppm, previously assigned to TAH, is associated with the silicate structure of C-A-S-H on the atomic level. We show using density functional theory (DFT) calculations that the ${ }^{29} \mathrm{Si}$ chemical shift of the associated silicates is consistent with species that are bonded to $\mathrm{Al}(\mathrm{VI})$ units at bridging sites within the chain. ${ }^{62}$ Our findings are inconsistent with the TAH hypothesis, and we determine that $\mathrm{Al}(\mathrm{VI})$ is incorporated into bridging sites within the silicate chain framework of C-A-S-H at high $\mathrm{Ca}: \mathrm{Si}$, high $\mathrm{H}_{2} \mathrm{O}: \mathrm{Si}$, and low $\mathrm{Al}: \mathrm{Si}$ ratios.

\section{EXPERIMENTAL SECTION}

Generation of C-A-S-H Structures. We utilized an extension of the C-S-H brick model ${ }^{29}$ permitting the incorporation of aluminate species. $\mathrm{A} \mathrm{SiO}_{2}$ unit is removed and an aluminum atom is added to the bridging site as $\mathrm{Al}(\mathrm{OH})_{2}{ }^{+}$to obtain six- and five-fold coordination geometry with interlayer calcium to compensate the charges. Similarly four-fold coordination is obtained by adding $\mathrm{AlO}(\mathrm{OH})$ units. The initial positions of water molecules are taken from $14 \AA$ tobermorite. Additional water molecules are added following the optimized positions obtained for C-S-H structural units as previously reported. $^{20,29}$ The Ca:Si ratio of C-A-S-H can be increased by the removal of bridging silicate tetrahedra ${ }^{7,19,28}$ and further increased by the addition of calcium at the bridging site. ${ }^{20}$ At $\mathrm{Ca}: \mathrm{Si}>1.5$, additional calcium ions are added to the interlayer space. ${ }^{19,20,28}$ Hydroxyl ions are added to the interlayer for charge compensation.

DFT Calculations. We used ultrasoft pseudopotentials with a van der Waals correction (DFT-D2 method), ${ }^{63}$ the Monkhorst-Pack $k$ point mesh of $2 \times 2 \times 1$, and a plane wave cutoff of $80 \mathrm{Ry}$ for the structural optimization as implemented in the Quantum Espresso package. ${ }^{64} \mathrm{~A}$ dense mesh was sometimes employed to cross-check the convergence of certain structures. To confirm the accuracy of the calculated relative energies, we carried out calculations with a PBEO hybrid functional ${ }^{65}$ with an exact exchange fraction of 0.25 , which gave a very consistent value with the PBE-D2 method (within 0.01 $\mathrm{eV}$ ). Additionally, we did not observe any impact on local relaxation of the geometries under consideration using a supercell calculation with two structural units (for details see SI section 1.4). The VESTA software has been used for structure visualization. ${ }^{66}$

The isotropic chemical shift calculations were calibrated by comparing calculated isotropic shielding parameters and experimental ${ }^{27} \mathrm{Al}$ chemical shifts of $\alpha-\mathrm{Al}_{2} \mathrm{O}_{3},{ }^{67}$ andalusite, ${ }^{68}$ sillimanite, ${ }^{69}$ $\mathrm{Ca}_{3} \mathrm{Al}_{2} \mathrm{O}_{6},{ }^{70} \mathrm{Ca}_{3} \mathrm{Al}_{2}(\mathrm{OH})_{12},{ }^{70}$ and $\gamma-\mathrm{Al}(\mathrm{OH})_{3},{ }^{70}$ using the procedure described in the SI. The minerals $\alpha-\mathrm{SiO}_{2}$, andalusite, sillimanite, and belite were used for the ${ }^{29} \mathrm{Si}$ chemical shift calibration. ${ }^{71}$ The isotropic shielding parameters are calculated using the GIPAW method. ${ }^{62,72}$ For ${ }^{27} \mathrm{Al}$, quadrupolar coupling tensors, which arise from coupling of the nuclear quadrupole moment to the electric field gradient at the nucleus, were also calculated, taking $0.1403 \mathrm{~b}$ as the quadrupole moment of ${ }^{27} \mathrm{Al}^{73}$ We find a maximum deviation of $4 \mathrm{ppm}$ and 2 $\mathrm{MHz}$ respectively for the calculations of ${ }^{27} \mathrm{Al}$ chemical shifts and quadrupolar coupling constants $\left(C_{\mathrm{q}}\right.$, defined in the SI). The center-ofgravity of the ${ }^{27} \mathrm{Al}$ resonances plotted in Figure $3 \mathrm{~B}, \delta_{\text {iso }}$, is obtained by

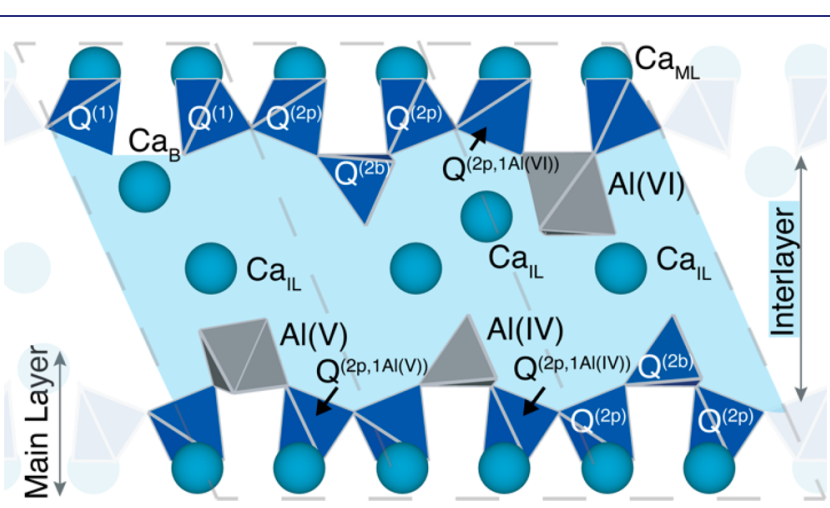

Figure 1. Schematic showing three C-A-S-H structural units representing the layered bulk structure of C-A-S-H. The dashed lines indicate the structural unit cell boundaries. ${ }^{29}$ The calcium atoms are shown as turquoise spheres. The interlayer is shown in light blue color depicting the presence of water and hydroxyl ions, which are omitted for clarity, in addition to interlayer calcium ions $\left(\mathrm{Ca}_{\mathrm{IL}}\right)$. The silicate species (dark blue) are labeled based on their connectivity and position. The polyhedral shapes of aluminum are shown in gray. 


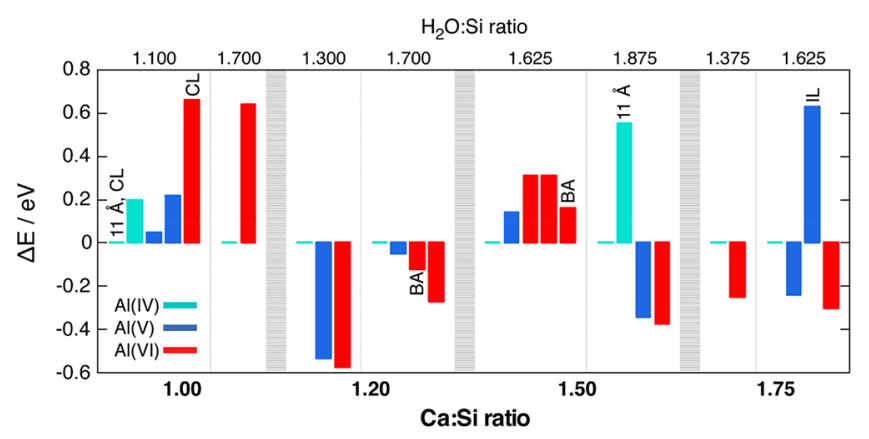

Figure 2. Relative energies of bridging aluminates according to coordination $(\Delta E)$ from C-A-S-H structural units of different $\mathrm{Ca}: \mathrm{Si}$ and $\mathrm{H}_{2} \mathrm{O}: \mathrm{Si}$ ratios. Thick vertical dashed gray lines divide the results into four regions on the basis of $\mathrm{Ca}: \mathrm{Si}$ ratio, whereas thin vertical dashed gray lines subdivide each region of fixed $\mathrm{Ca}: \mathrm{Si}$ ratio into two regions of fixed $\mathrm{H}_{2} \mathrm{O}: \mathrm{Si}$ ratios, yielding eight panels of fixed composition. Within each panel, the most stable C-A-S-H unit with $\mathrm{Al}$ in tetrahedral coordination is taken as the reference with a relative energy of $\Delta E=0$. In certain cases, special properties of the optimized structure are noted: $11 \AA, 11 \AA$ tobomorite framework; CL, crosslinking aluminate; $\mathrm{BA}, \mathrm{Al}-\mathrm{OH}-\mathrm{Si}$ Brønsted acid hydroxysilicate bond; IL, interlayer aluminate (instead of bridging). The numerical values and corresponding structural models are shown in the SI.

including the isotropic second-order quadrupolar shift for a spin $I=$ $5 / 2$ nucleus according to

$$
\delta_{\text {iso }}=\delta_{\text {iso }, \mathrm{cs}}-\frac{3}{500}\left(\frac{C_{\mathrm{q}}}{v_{0}}\right)^{2}\left(\frac{\eta_{\mathrm{q}}^{2}}{3}+1\right)
$$

$\delta_{\text {iso,cs }}$ is the isotropic chemical shift, $\nu_{0}=234.730 \mathrm{MHz}$ for a magnetic field of $21.141 \mathrm{~T}$, and $\eta_{\mathrm{q}}$ (defined in the SI) is the asymmetry parameter of the quadrupolar coupling tensor. ${ }^{74,75}$ The maximum magnitude of the correction to the isotropic ${ }^{27} \mathrm{Al}$ chemical shift is 14 ppm for the aluminate systems studied here. with

The line shape of a given resonance is plotted in Figures $3 \mathrm{~B}$ and $4 \mathrm{~B}$

$$
S(\delta)=\frac{1}{\sqrt{2 \pi R^{2}}} \exp \left[-\frac{1}{2}\left(\frac{\delta-\delta_{\text {iso }}}{R}\right)^{2}\right]
$$

where $R$ is the root-mean-square deviation of the respective population (between 1 and $2.5 \mathrm{ppm}$ ). Line shape asymmetry due to the anisotropic second-order quadrupolar interaction is neglected by this parametrization. Typical input files are given in the SI.

Molecular Dynamics. Classical molecular dynamics simulation were done using DLPOLY ${ }^{76}$ with an improved CementFF2 force field. $^{29,77,78}$ The details of the improved interaction parameters can be found in Section 1.7 of the SI. The simulations were done with a time step of 0.2 fs with a Coulombic cutoff radius of $8.5 \AA$. A constanttemperature and constant-stress ensemble with the Nose-Hoover thermostat and barostat as implemented in the DLPOLY package was used for the simulations. The structures were annealed at $1000 \mathrm{~K}$ for $300 \mathrm{ps}$ followed by equilibration at $300 \mathrm{~K}$ for $1.4 \mathrm{~ns}$. The input files are also included in the SI material and in the force field database for cementitious materials: https://www.cemff.org.

Synthesis of C-A-S-H. C-A-S-H samples were prepared using the dropwise synthesis method described by Kumar et al. ${ }^{20}$ Aluminum nitrate nonahydrate $\left(\mathrm{Al}\left(\mathrm{NO}_{3}\right)_{3} \cdot 9 \mathrm{H}_{2} \mathrm{O}\right.$, Merck $\mathrm{KGaA}$, CAS: 7784-272) was mixed in the calcium nitrate solution $(100 \mathrm{~mL}$ of $0.2 \mathrm{M}$, $\mathrm{Ca}\left(\mathrm{NO}_{3}\right)_{2} \cdot 4 \mathrm{H}_{2} \mathrm{O}$, Fluka Chemicals, CAS: $\left.13477-34-4\right)$. This solution was constantly added to a sodium silicate solution $\left(\mathrm{Na}_{2} \mathrm{SiO}_{3}\right.$, SigmaAldrich, CAS: 6834-92-0) in the stirring tank under $\mathrm{N}_{2}$ gas to eliminate carbonate formation. The $\mathrm{pH}$ was adjusted with sodium hydroxide $(\mathrm{NaOH}$, Acros Organic, CAS: 1310-73-2) to reach an initial $\mathrm{pH}$ of 13.5. The precipitates were then vacuum filtered after $3 \mathrm{~h}$
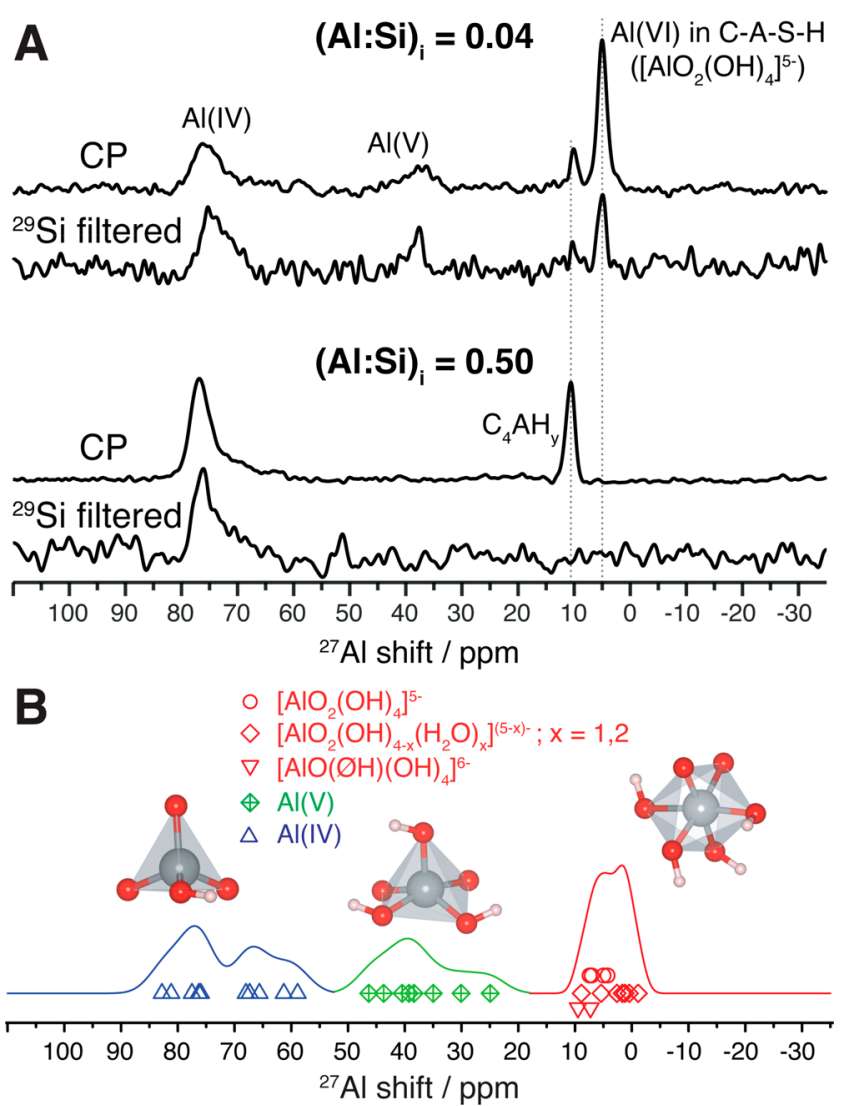

Figure 3. (A) DNP-enhanced ${ }^{27} \mathrm{Al}$ CP MAS spectra at $21.14 \mathrm{~T}, 100$ $\mathrm{K}$, and $12.5 \mathrm{kHz}$ MAS for synthetic C-A-S-H samples having a $\mathrm{Ca}: \mathrm{Si}$ ratio of 2.0 and initial $\mathrm{Al}: \mathrm{Si}$ ratios of 0.04 (top) and 0.50 (bottom), with and without the insertion of a ${ }^{29} \mathrm{Si}$ filter. The $\mathrm{CP}$ selects for nuclei in proton-containing phases. Additionally, the ${ }^{29} \mathrm{Si}$ filter selects NMR signal from those ${ }^{27} \mathrm{Al}$ nuclei in proximity to ${ }^{29} \mathrm{Si}$ nuclei. The ${ }^{29} \mathrm{Si}$ filtering is achieved using a refocused dipolar INEPT sequence. $\mathrm{C}_{4} \mathrm{AH}_{y}$ is shorthand for hydroxylated AFm phases. (B) Calculated ${ }^{27} \mathrm{Al}$ shifts for the C-A-S-H structures described in Figure 2. The line shapes are drawn from the calculated isotropic shifts corresponding to four-(green) five- (blue) and six-fold (red) coordination of aluminum. $\varnothing \mathrm{H}$ is shorthand for a Brønsted acid hydroxysilicate bond, $\mathrm{Al}-\mathrm{OH}-$ Si.

and then washed with an ultrapure 50:50 volume solution of water and ethanol.

DNP-Enhanced Solid-State NMR. Most samples were prepared by partial drying of C-A-S-H gel on a watch glass to densify them. All samples were packed into $3.2 \mathrm{~mm}$ zirconia rotors, plugged with a PTFE insert, and topped with a zirconia drive cap. AMUPol ${ }^{79}$ was usually added as a $1 \mathrm{M} \mathrm{NaOH}$ solution or dissolved directly into the gel. NMR was carried out on many sample variants; details and supplemental NMR spectra are given in the SI. Experiments were carried out on commercial Bruker DNP NMR spectrometers at nominal field strengths of 21.14 or $9.40 \mathrm{~T}$ equipped with $3.2 \mathrm{~mm}$ MAS DNP probes in ${ }^{1} \mathrm{H} /{ }^{27} \mathrm{Al} /{ }^{29} \mathrm{Si}$ configuration. The probe was cooled below $100 \mathrm{~K}$ prior to insertion of the samples. The DNP enhancements were measured as the ratio of the $\left\{{ }^{1} \mathrm{H}\right\}^{27} \mathrm{Al}$ crosspolarization $(\mathrm{CP})^{80}$ signal intensity between spectra acquired with and without microwaves. For $\left\{{ }^{29} \mathrm{Si}\right\}^{27} \mathrm{Al}$ refocused dipolar INEPT experiments ${ }^{81}$ a $\left\{{ }^{1} \mathrm{H}\right\}^{29} \mathrm{Si} \mathrm{CP}$ transfer under DNP was used to initially hyperpolarize ${ }^{29} \mathrm{Si}$. The $x y-8$ REDOR cycle ${ }^{82}$ was used to recouple the ${ }^{29} \mathrm{Si}$ and ${ }^{27} \mathrm{Al}$ nuclei under MAS. This implementation of the refocused dipolar INEPT pulse sequence is identical to the "DNP-enhanced CPTEDOR" experiment used by Hanrahan et al. ${ }^{83}$ The spectrum in Figure 4 is referenced externally to the $\mathrm{Al}\left(\mathrm{NO}_{3}\right)_{3}$ standard by setting the ${ }^{27} \mathrm{Al} \mathrm{NMR}$ signal maximum of boehmite to $7 \mathrm{ppm} .{ }^{84}$ All other 

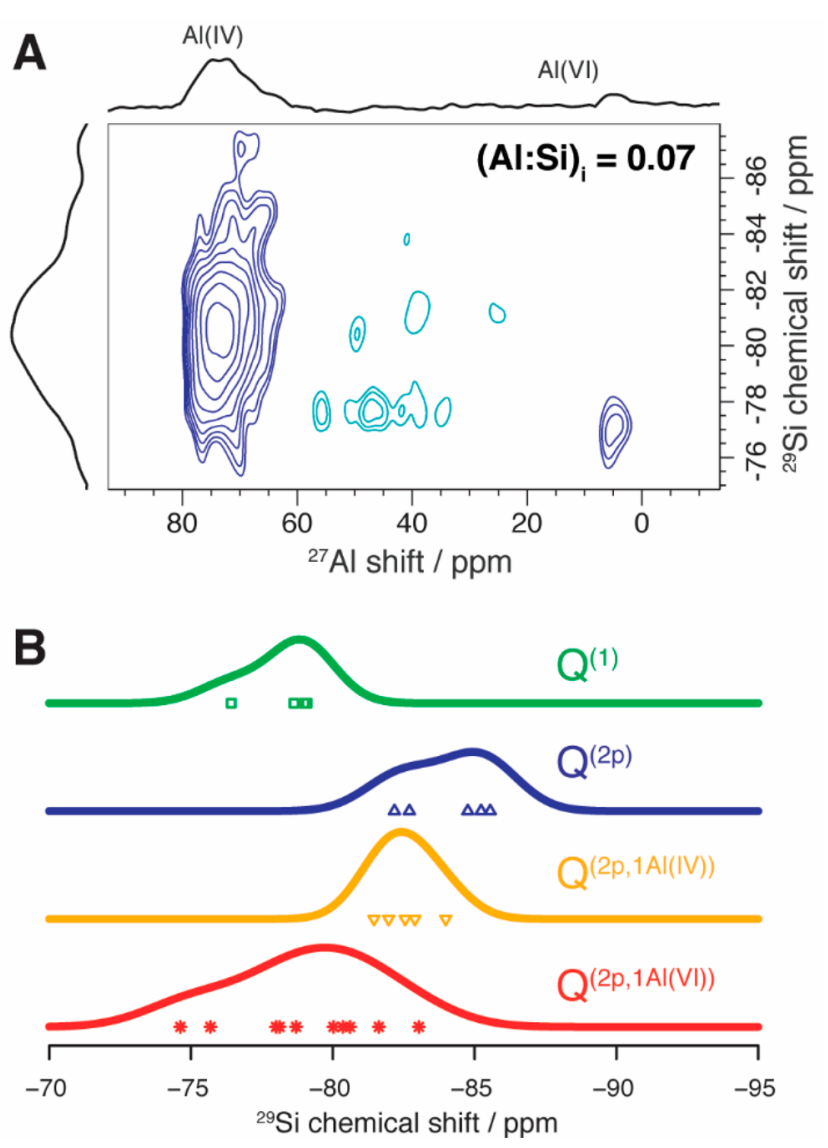

Figure 4. (A) DNP-enhanced $2 \mathrm{D}\left\{{ }^{29} \mathrm{Si}\right\}{ }^{27} \mathrm{Al}$ refocused dipolar INEPT MAS spectrum at $9.40 \mathrm{~T}, 100 \mathrm{~K}$, and $10 \mathrm{kHz}$ MAS for a synthetic CA-S-H sample having a $\mathrm{Ca}: \mathrm{Si}$ ratio of 2.0 and an $(\mathrm{Al}: \mathrm{Si})_{\mathrm{i}}$ ratio of 0.07 . (B) DFT-calculated ${ }^{29} \mathrm{Si}$ isotropic chemical shifts of the C-A-S-H structural units plotted according to $\mathrm{Q}^{(n)}$ speciation.

spectra were referenced by setting the $Q^{(1)}$ maximum of the highresolution ${ }^{29} \mathrm{Si}$ NMR spectrum of $\mathrm{C}-\mathrm{A}-\mathrm{S}-\mathrm{H}$ with an initial $(\mathrm{Al}: \mathrm{Si})_{\mathrm{i}}$ ratio of 0.04 to $-79.5 \mathrm{ppm}^{23}$ More details regarding experimental parameters are given in the SI.

\section{RESULTS AND DISCUSSION}

Factors Affecting Stability of Aluminate Species in CA-S-H. A C-A-S-H structure constructed using the brick model is illustrated in Figure 1. As with $\mathrm{C}-\mathrm{S}-\mathrm{H}$, the structure comprises linear silicate chains flanking a $\mathrm{CaO}$ main layer, $\mathrm{Ca}_{\mathrm{ML}}$. In addition to "pairing" silicates $\left(\mathrm{Q}^{(2 \mathrm{p})}\right.$, where the "2" indicates the number of oxygen atoms of the silicate tetrahedron that bond to other silicate or aluminate units) and interlayer-protruding "bridging" $\left(\mathrm{Q}^{(2 \mathrm{~b})}\right)$ silicate species, we observe defects where $\mathrm{Q}^{(1)}$ silicate species terminate the chains, which often occur when a bridging calcium site, $\mathrm{Ca}_{\mathrm{B}}$, substitutes for $\mathrm{Q}^{(2 \mathrm{~b})} \cdot{ }^{20}$ The interlayer contains water and calcium as $\mathrm{Ca}^{2+}$ or $\mathrm{CaOH}^{+}$ions or $\mathrm{Ca}(\mathrm{OH})_{2}$ units, ${ }^{7,29}$ each generically represented as $\mathrm{Ca}_{\mathrm{IL}}$ species in Figure 1. Our structure also accommodates the inclusion of four-, five- and six-fold-coordinate aluminate species into the silicate chains or in the interlayer. We also classify $\mathrm{Q}^{(n)}$ species according to the number and type of aluminate species to which they are bonded. For example, the $\mathrm{Q}^{(2 \mathrm{p}, 1 \mathrm{Al}(\mathrm{VI}))}$ species shown in Figure 1 indicates a silicate in the pairing position bonded to one other silicate and an $\mathrm{Al}(\mathrm{VI})$ octahedron. Similar to previous works, ${ }^{20,29}$ we can represent the complex bulk structure of
C-A-S-H by tessellating structural units containing different chemical species arranged in the crystallographic positions of a tobermorite lattice framework, usually $14 \AA$ tobermorite, where the distance quantifies the main layer separation.

Our interest is in the energetics of aluminate species inserted into bridging sites of the silicate chains or the interlayer space considering structural units with different $\mathrm{Ca}: \mathrm{Si}$ ratios. We investigated this using DFT calculations. The results are shown in Figure 2, which compares the relative energies due to the different coordination geometries of aluminum at a fixed stoichiometry. Results are shown for eight different compositions. At a $\mathrm{Ca}: \mathrm{Si}$ ratio of 1.0 , which is generally lower than encountered in industrially relevant cement formulations, ${ }^{1}$ our calculations conform to existing structural models of $\mathrm{Al}$ in C-A$\mathrm{S}-\mathrm{H}^{43,85} \mathrm{Al}(\mathrm{IV})$ is relatively stable, particularly in an $11 \AA$ tobermorite framework. In contrast, the energies of $\mathrm{Al}(\mathrm{VI})$ are more than $0.6 \mathrm{eV}$ greater than their respective references and are not expected to be stable aluminate species in C-A-S-H when the Ca:Si ratio is low. In two instances the calculations converged into cross-linked aluminate structures, where the aluminate bridges parallel silicate chains across the interlayer, a possibility noted in low $\mathrm{Ca} \mathrm{Si}$ ratio C-A-S-H. ${ }^{86}$ As the Ca:Si ratio increases, however, we find that bridging $\mathrm{Al}(\mathrm{V})$ and $\mathrm{Al}(\mathrm{VI})$ species may be more stable than $\mathrm{Al}(\mathrm{IV})$ species. Indeed, at the highest $\mathrm{Ca}$ :Si ratio (1.75), we calculate that $\mathrm{Al}(\mathrm{VI})$ is about $0.3 \mathrm{eV}$ more stable than the corresponding $\mathrm{Al}(\mathrm{IV})$ unit. We also find that the stabilization of $\mathrm{Al}(\mathrm{V})$ is intermediate, being less unstable than $\mathrm{Al}(\mathrm{VI})$ at low $\mathrm{Ca}: \mathrm{Si}$ ratios but less stable than $\mathrm{Al}(\mathrm{VI})$ at higher $\mathrm{Ca}: \mathrm{Si}$ ratios. On the basis of our results we would not exclude the presence of bridging $\mathrm{Al}(\mathrm{V})$ in C-A-S-H at any given Ca:Si ratio. Diffraction studies have suggested that $\mathrm{Al}(\mathrm{V})$ is more likely to reside in the interlayer than as a bridging $\mathrm{Al}(\mathrm{V})$ unit. $^{37,38}$ We find that aluminates in the interlayer indeed relax into a 5-fold coordination geometry regardless of initial coordination geometry; however, the relative energy of such a structure is quite high, as can be seen in Figure 2 for $\mathrm{Ca}: \mathrm{Si}=1.75$ and $\mathrm{H}_{2} \mathrm{O}: \mathrm{Si}=1.625$. We thus infer that isolated interlayer aluminates in C-A-S-H are less stable than bridging aluminates.

We note that cross-linking aluminates are never found in any structure having $\mathrm{Ca}: \mathrm{Si}>1.0$. At such $\mathrm{Ca}: \mathrm{Si}$ ratios we also note that some of the optimized $\mathrm{Al}(\mathrm{VI})$ structures ("BA" in Figure 2) feature hydroxysilicate bonds, structures that exhibit Brønsted acidity, at insignificant energy penalties $(<0.1 \mathrm{eV})$ (local structure shown in Figure S6). Such bonding has been reported for tetrahedrally coordinated aluminate on a silicate surface. ${ }^{56}$

These trends may be explained by the presence of hydroxyl groups associated with the additional water and interlayer calcium ions as $\mathrm{H}_{2} \mathrm{O}: \mathrm{Si}$ and $\mathrm{Ca}: \mathrm{Si}$ ratios increase. Our optimized structures indicate a tendency for hydroxyl groups to enter the first coordination shell of bridging $\mathrm{Al}(\mathrm{VI})$ aluminate species. We infer that hydroxyl ligands aid in the stabilization of $\mathrm{Al}(\mathrm{VI})$ units in the silicate chain. For the low $\mathrm{Ca}$ :Si ratio of 1.0, the lower hydroxyl content $\left(\mathrm{OH}^{-}: \mathrm{Si}\right.$ ratio of 0.2 versus 1.25 for a $\mathrm{Ca}: \mathrm{Si}$ ratio of 1.75 ) favors bridging $\mathrm{Al}(\mathrm{IV})$ over $\mathrm{Al}(\mathrm{VI})$ species, consistent with previous experimental ${ }^{43,85}$ and theoretical studies. ${ }^{35,36,44}$ With respect to water itself, our calculations indicate that the relative stability of $\mathrm{Al}(\mathrm{VI})$ is often independent of local water structure, except for a $\mathrm{Ca}$ :Si ratio of 1.5 , where in our structures $\mathrm{Al}(\mathrm{VI})$ possesses a water ligand, $\left[\mathrm{AlO}_{2}(\mathrm{OH})_{3}\left(\mathrm{H}_{2} \mathrm{O}\right)\right]^{4-}$. In this case, higher water content stabilizes the water molecule coordinated to the $\mathrm{Al}(\mathrm{VI})$ 
through greater proliferation of a hydrogen-bonding network, as shown in Figure S5. At low $\mathrm{Ca}: \mathrm{Si}$ ratio, the stable tetrahedrally coordinated aluminate does not accept any water molecules even at a high $\mathrm{H}_{2} \mathrm{O}: \mathrm{Si}$ ratio of 1.7. For a $\mathrm{Ca}: \mathrm{Si}$ ratio of 1.75 , the stable $\mathrm{Al}(\mathrm{VI})$ is coordinated to four hydroxyl ions and two oxygen atoms of the silicate tetrahedra, and no additional water molecule encroaches on the first coordination shell. In this case no destabilization occurs when water is removed from the interlayer. These results are in contrast to previous reports that $\mathrm{Al}(\mathrm{VI})$ may exist in $\mathrm{C}-\mathrm{A}-\mathrm{S}-\mathrm{H}$ as long as there is a strong association of the $\mathrm{AlO}_{6}$ octahedron with water molecules. ${ }^{44,8} 7$

Generally, the uptake of aluminum in Portland cement is limited to an $\mathrm{Al}: \mathrm{Si}$ ratio of roughly $0.1,{ }^{88,89}$ approaching 0.3 with alumina-rich additions or in alkali activated materials. $^{90-92}$ The Al:Si ratio of the structures studied here are either 0.20 or 0.25 . By placing a C-A-S-H structural unit or brick adjacent to a C-S-H brick we can create a structure with a lower Al:Si ratio, as described in section 1.4 of the SI. For such a structure having $\mathrm{Ca}: \mathrm{Si}=1.55$ and $\mathrm{Al}: \mathrm{Si}=0.11$ we find $\Delta E=$ $-0.8 \mathrm{eV}$ for $\mathrm{Al}(\mathrm{VI})$, yielding an even greater stabilization per aluminate unit than the structures described in Figure 2. This is expected, as lower overall aluminum concentration reduces competition for the available $\mathrm{OH}^{-}$necessary for $\mathrm{Al}(\mathrm{VI})$ stabilization.

To validate our model, we calculated the nanomechanical properties of a few C-S-H and C-A-S-H structural units and discuss the results in Section 1.5 of the SI. Our models correctly capture the nanomechanical properties determined experimentally by synchrotron radiation-based high-pressure X-ray diffraction by Geng et al. ${ }^{86,93}$

These calculations suggest that stable $\mathrm{Al}(\mathrm{VI})$ species can be incorporated into the silicate chains of C-A-S-H at sufficiently high Ca:Si ratios, substituting for bridging $\mathrm{Q}^{(2 \mathrm{~b})}$ species in the silica chain framework. To support this hypothesis, we turn to state-of-the-art synthetic and solid-state NMR methods.

DNP-Enhanced NMR of C-A-S-H. Experimental studies of C-A-S-H are complicated by the material complexity of hydrated cement which contains several phases in addition to the C-A-S-H. To reduce the ambiguity caused by these phases, our study takes advantage of the recently introduced rapid precipitation method, ${ }^{20}$ which was shown to eliminate undesired solid phases such as $\mathrm{Ca}(\mathrm{OH})_{2}$ and $\mathrm{Ca}_{3} \mathrm{SiO}_{5}$, which are often unavoidable when using conventional methods. The product is essentially pure $\mathrm{C}-\mathrm{S}-\mathrm{H}$ with a controllable $\mathrm{Ca} \mathrm{Si}$ ratio. Extending of this method to synthesize C-A-S-H with controllable $\mathrm{Al}: \mathrm{Si}$ ratio is achieved by adding a specific concentration of an aqueous aluminum nitrate solution to the aqueous calcium nitrate reagent solution. Sulfate and iron species are entirely absent from the synthesis, such that the final C-A-S-H product is free of paramagnetic $\mathrm{Fe}^{3+}$ impurities that can impair the resolution and sensitivity of samples prepared from real cements. ${ }^{87,94}$

To enable the low-sensitivity $1 \mathrm{D}$ and $2 \mathrm{D}\left\{{ }^{29} \mathrm{Si}\right\}{ }^{27} \mathrm{Al}$ solidstate NMR experiments required to probe the relationship between $\mathrm{Al}$ and $\mathrm{Si}$, we prepared C-A-S-H formulations that would yield enhancement of NMR signals by MAS DNP. ${ }^{20,47-49}$ This is crucial since our samples were synthesized without ${ }^{29} \mathrm{Si}$ isotopic enrichment. The formulation for DNP is accomplished by incorporating a small amount of the organic biradical AMUPol in the sample, ${ }^{79}$ whose properties are tailored to provide efficient transfer of large electron polarization to protons in the sample, which is frozen at $100 \mathrm{~K}$ during MAS experiments so that proton spin diffusion spontaneously transports the enhanced polarization throughout the sample. Once the bulk is hyperpolarized, the enhanced ${ }^{1} \mathrm{H}$ magnetization can be transferred to ${ }^{29} \mathrm{Si}$ or ${ }^{27} \mathrm{Al}$ nuclei by $\mathrm{CP}^{80}$

To aid formation of a glassy matrix in aqueous formulations, $d_{8}$-glycerol is usually added; however, glycerol was observed to induce a transformation of the $\mathrm{Al}(\mathrm{VI})$ species associated with the $5 \mathrm{ppm}{ }^{27} \mathrm{Al} \mathrm{NMR}$ signal into $\mathrm{Al}(\mathrm{IV})$ and $\mathrm{Al}(\mathrm{V})$ species, as shown in the SI, Figure S11. This is attributed to dehydration due to the hygroscopic nature of glycerol. Fortunately, it was possible to use the intrinsic cryoprotectant properties of C-A$\mathrm{S}-\mathrm{H}$ and achieve adequate enhancements by dissolving AMUPol directly into the sample. DNP enhancements, as analyzed by comparing ${ }^{27} \mathrm{Al}$ and ${ }^{29} \mathrm{Si} \mathrm{CP}$ NMR spectra acquired with and without microwave irradiation, of around 40 at $9.40 \mathrm{~T}$ and around 3 at $21.14 \mathrm{~T}$ were typical for both nuclei. The addition of a basic $(\mathrm{pH} \sim 13) \mathrm{NaCl}$ solution was necessary to achieve DNP enhancements over 4 at $21.14 \mathrm{~T}$, possibly due to a dielectric effect. ${ }^{95}$ Unlike glycerol, the addition of the $\mathrm{NaCl}$ solution leaves most of the $\mathrm{Al}(\mathrm{VI})$ signal at $5 \mathrm{ppm}$ intact, as seen in the SI, Figure S11. This formulation improves DNP enhancements to around 8 .

Figure $3 \mathrm{~A}$ compares two different DNP-enhanced $1 \mathrm{D}{ }^{27} \mathrm{Al}$ CP MAS NMR experiments for C-A-S-H samples with a $\mathrm{Ca}: \mathrm{Si}$ ratio of 2.0 and two different initial $(\mathrm{Al}: \mathrm{Si})_{\mathrm{i}}$ ratios. Here "initial" refers to the Al:Si ratio of the reagent solutions, as we do not determine the Al:Si ratio of the C-A-S-H product. At an $(\mathrm{Al}: \mathrm{Si})_{\mathrm{i}}$ ratio of 0.04 , the conventional CP spectrum shows four different aluminum species. They cluster in three regions around 75,40 , and $5 \mathrm{ppm}$, corresponding to the well-known shifts of $\mathrm{Al}(\mathrm{IV}), \mathrm{Al}(\mathrm{V})$, and $\mathrm{Al}(\mathrm{VI})$ aluminates, respectively. These regions are also shown in Figure $3 \mathrm{~B}$, where isotropic ${ }^{27} \mathrm{Al}$ shifts (including an isotropic second-order quadrupolar shift contribution derived from the calculated quadrupolar coupling tensor) calculated from the structures are shown in Figure 2 for different types of $\mathrm{Al}$ using the GIPAW method. $^{62,72}$ The signals in the $\mathrm{Al}(\mathrm{IV})$ region and $\mathrm{Al}(\mathrm{V})$ regions are broad, consistent with expected quadrupolar coupling constants $\left(\left|C_{\mathrm{q}}\right|\right)$ generally exceeding $3 \mathrm{MHz}$, which lead to an anisotropic second-order quadrupolar broadening that persists under MAS. This broadening is inversely proportional to the magnetic field, and at the high $21.14 \mathrm{~T}$ field used here the $\mathrm{Al}(\mathrm{IV})$ and $\mathrm{Al}(\mathrm{V})$ signal regions do not overlap. For an $(\mathrm{Al}: \mathrm{Si})_{\mathrm{i}}$ ratio of 0.50 , we note that $\mathrm{Al}(\mathrm{V})$ is essentially absent. Sharp $\mathrm{Al}(\mathrm{IV})$ signals at $72 \mathrm{ppm}$, observed with some C-A-S-H formulations at lower $\mathrm{Ca}: \mathrm{Si}$ ratios, ${ }^{39}$ are not observed here.

The $\mathrm{Al}(\mathrm{VI})$ signals have much lower $\left|C_{\mathrm{q}}\right|$ near $1 \mathrm{MHz},{ }^{32}$ which mitigates second-order quadrupolar effects, leading to much narrower peaks. For $(\mathrm{Al}: \mathrm{Si})_{\mathrm{i}}=0.04$ at $21.14 \mathrm{~T}$ two distinct $\mathrm{Al}(\mathrm{VI})$ signals with respective maxima at 5.0 and 10.1 ppm are resolved. The signal at $5.0 \mathrm{ppm}$, known to be associated with the presence of C-A-S-H, is dominant in the spectrum for the sample synthesized with $(\mathrm{Al}: \mathrm{Si})_{\mathrm{i}}=0.04$ but is absent at $(\mathrm{Al}: \mathrm{Si})_{\mathrm{i}}=0.50$. Conversely, we see that for $(\mathrm{Al}: \mathrm{Si})_{\mathrm{i}}=$ 0.50 the $5.0 \mathrm{ppm}$ signal is absent and a single narrow $\mathrm{Al}(\mathrm{VI})$ signal with a maximum at $10.5 \mathrm{ppm}$ is observed. Narrow signals in the 8 to $14 \mathrm{ppm}$ range are commonly observed in the ${ }^{27} \mathrm{Al} \mathrm{NMR}$ of aluminum-containing cements as a consequence of numerous crystalline $\mathrm{Al}(\mathrm{VI})$ phases that result from cement hydration, such as (but not limited to) ettringite, AFm phases, 
and siliceous hydrogarnet. ${ }^{31,70}$ Our formulation is free of sulfates and iron, so we assign the $\mathrm{Al}(\mathrm{VI})$ signal at $10.5 \mathrm{ppm}$ to the hydroxylated AFm phases $\mathrm{Ca}_{4}\left[\mathrm{Al}(\mathrm{OH})_{6}\right]_{2}(\mathrm{OH})_{2} \cdot y \mathrm{H}_{2} \mathrm{O}, y$ = 4-12, which provide the best agreement with the observed shift and low $\left|C_{\mathrm{q}}\right|$ values (ca. $1 \mathrm{MHz}$ ) implied by the narrowness of the peak. ${ }^{37}$ The signal at $10.1 \mathrm{ppm}$ for $(\mathrm{Al}: \mathrm{Si})_{\mathrm{i}}=$ 0.04 may also be from such phases, though this assignment is less certain. Figure S11 shows the ${ }^{27} \mathrm{Al}$ NMR spectrum of a CA-S-H gel with $(\mathrm{Al}: \mathrm{Si})_{i}=0.04$ where exposure to dry air was minimized during preparation of the NMR sample. In this case, the $10.5 \mathrm{ppm}$ signal is entirely absent. Even mildly desiccating conditions, however, lead to the appearance of hydroxylated $\mathrm{AFm}$ phases and a greater proportion of $\mathrm{Al}(\mathrm{IV})$ species at the expense of $\mathrm{Al}(\mathrm{VI})$ signal at $5 \mathrm{ppm}$. This suggests the formation of extraneous solids such as the hydroxylated AFm phases is a decomposition process driven by the loss of structural water, at least at low $\mathrm{Al}: \mathrm{Si}$ ratios.

In the predicted shifts plotted in Figure $3 \mathrm{~B}$, we note a systematic trend to slightly lower shifts when one or more $\mathrm{H}_{2} \mathrm{O}$ molecules complex $\mathrm{Al}(\mathrm{VI})$. We identify the cause as a systematically larger (negative) isotropic second-order quadrupolar shift for these species due to larger calculated $\left|C_{\mathrm{q}}\right|$ values (up to $10 \mathrm{MHz}$ for $\left[\mathrm{AlO}_{2}(\mathrm{OH})_{(4-x)}\left(\mathrm{H}_{2} \mathrm{O}\right)_{x}\right]^{(5-x)-} ; x=$ 1 , 2, but less than $3 \mathrm{MHz}$ for $\left[\mathrm{AlO}_{2}(\mathrm{OH})_{4}\right]^{5-}$ species, as shown in the SI). Such large $\left|C_{\mathrm{q}}\right|$ values would also lead to a secondorder quadrupolar broadening of the $\mathrm{Al}(\mathrm{VI})$ signal comparable to that of the $\mathrm{Al}(\mathrm{IV})$ and $\mathrm{Al}(\mathrm{V})$ sites, which we do not observe. This ties in with the results of our stability calculations that $\mathrm{Al}(\mathrm{VI})$ in C-A-S-H exists primarily as $\left[\mathrm{AlO}_{2}(\mathrm{OH})_{4}\right]^{5-}$ and is consistent with the key structural finding of Andersen et al., although they ascribed the signal to the TAH phase. ${ }^{32}$

These inferences are affirmed by DNP-enhanced ${ }^{29} \mathrm{Si}$ filtered ${ }^{27} \mathrm{Al}$ NMR experiments, shown in Figure $3 \mathrm{~A}$ immediately below the CP spectra. In such experiments, DNP-enhanced ${ }^{1} \mathrm{H}$ polarization is first transferred to ${ }^{29} \mathrm{Si}$ nuclei by $\mathrm{CP}$, followed by transfer to ${ }^{27} \mathrm{Al}$ for detection. A refocused dipolar INEPT sequence is used for the transfer to ${ }^{27} \mathrm{Al},{ }^{81}$ which is mediated by the through-space dipolar coupling between ${ }^{29} \mathrm{Si}$ and ${ }^{27} \mathrm{Al}$ nuclei. The strength of the interaction scales as $r^{-3}$, where $r$ is the distance between the two nuclei. Thus, dipolar-mediated transfer allows us to selectively observe only those ${ }^{27} \mathrm{Al}$ close enough to ${ }^{29} \mathrm{Si}$ nuclei to allow magnetization transfer. A soft cutoff can be defined as the distance where half the initial magnetization is transferred to the target. ${ }^{96-99}$ Therefore, this experiment filters out aluminum species that are too far away to receive magnetization from ${ }^{29} \mathrm{Si}$, as would occur if ${ }^{27} \mathrm{Al}$ exists in a silicon-free phase.

For the spectra in Figure 3A, short recoupling intervals, which probe distances up to $2.46 \AA$, were selected such that transfer of magnetization from ${ }^{29} \mathrm{Si}$ to ${ }^{27} \mathrm{Al}$ only occurs between aluminate species that are directly bonded to silicates. We see that each of the signals we associate with $\mathrm{C}-\mathrm{A}-\mathrm{S}-\mathrm{H}$, when present in the ordinary ${ }^{27} \mathrm{Al} \mathrm{CP}$ spectrum, are also present in the ${ }^{29} \mathrm{Si}$ filtered spectrum. Crucially, the $\mathrm{Al}(\mathrm{VI})$ signal at 5.0 ppm survives the ${ }^{29} \mathrm{Si}$ filtering, and we determine that this $\mathrm{Al}(\mathrm{VI})$ species exists within a silicate-containing phase: $C-A-S-H$. This finding is incompatible with the conventional assignment of this signal to a silicate-free TAH phase.

Conversely, the hydroxylated AFm signal is eliminated by the refocused dipolar INEPT sequence, evident when comparing the $\mathrm{CP}$ and ${ }^{29} \mathrm{Si}$ filtered spectra of the sample synthesized with an $(\mathrm{Al}: \mathrm{Si})_{\mathrm{i}}$ ratio of 0.50 . This finding is fully consistent with the lack of $\mathrm{Si}$ in the hydroxylated AFm phases.
Furthermore, siliceous hydrogarnets, whose ${ }^{27} \mathrm{Al}$ NMR signals have been assigned to $\mathrm{Al}(\mathrm{VI})$ near $11 \mathrm{ppm},{ }^{100}$ also contain $\mathrm{AlO}_{6}-\mathrm{SiO}_{4}$ binding motifs. ${ }^{101}$ The elimination of the 10.5 ppm signal by the nearest-neighbor silicate filtering shows that for Al-rich C-A-S-H synthesized by rapid precipitation siliceous hydrogarnet phases are not formed. The sequestration of Ca by hydroxylated AFm phases and the high $\mathrm{Al}$ content might have resulted in the formation of a low $\mathrm{Ca}$ : $\mathrm{Si}+\mathrm{Al})$ ratio $\mathrm{C}-\mathrm{A}-\mathrm{S}-\mathrm{H}$. A lower calcium concentration with respect to the amount of aluminum incorporated would decrease the hydroxyl concentration necessary for stable $\mathrm{Al}(\mathrm{VI})$ species, instead favoring $\mathrm{Al}(\mathrm{IV})$ as observed.

Assignment of the $5 \mathrm{ppm}{ }^{27} \mathrm{Al}$ NMR Signal to Bridging $\mathrm{Al}(\mathrm{VI})$ in $\mathrm{C}-\mathrm{A}-\mathrm{S}-\mathrm{H}$. To determine a more precise location of $\mathrm{Al}(\mathrm{VI})$ within $\mathrm{C}-\mathrm{A}-\mathrm{S}-\mathrm{H}$, we performed a twodimensional version of the DNP-enhanced $\left\{{ }^{29} \mathrm{Si}\right\}{ }^{27} \mathrm{Al}$ refocused dipolar INEPT NMR experiment, which correlates the ${ }^{27} \mathrm{Al}$ resonance frequencies to ${ }^{29} \mathrm{Si}$ chemical shifts. Due to the extremely low sensitivity of the experiment, particularly given the low concentration of $\mathrm{Al}$ and with ${ }^{29} \mathrm{Si}$ present at the natural abundance of $4.67 \%$, this experiment was carried out on a C-A$\mathrm{S}-\mathrm{H}$ sample with an $(\mathrm{Al}: \mathrm{Si})_{\mathrm{i}}$ ratio of 0.07 at a lower magnetic field of $9.40 \mathrm{~T}$, where the cross-effect DNP mechanism performs better. ${ }^{46,47}$ This led to a net gain in sensitivity, largely due to DNP enhancements being an order of magnitude higher at $9.40 \mathrm{~T}$ relative to $21.14 \mathrm{~T}$, at the cost of a modest loss of resolution along the ${ }^{27} \mathrm{Al}$ dimension due to stronger secondorder quadrupolar effects at the lower field. A longer recoupling time, probing distances up to $4.33 \AA$, was also used to improve the sensitivity of the experiment.

The 2D DNP-enhanced $\left\{{ }^{29} \mathrm{Si}\right\}{ }^{27} \mathrm{Al}$ refocused dipolar INEPT correlation spectrum is shown in Figure 4A. Two main correlation peaks are observed. The most intense one correlates ${ }^{27} \mathrm{Al}$ in $\mathrm{Al}(\mathrm{IV})$ species to silicates with a distribution of ${ }^{29} \mathrm{Si}$ chemical shifts peaking at $-81 \mathrm{ppm}$. This corresponds to the well-known tetrahedral $\mathrm{Al}(\mathrm{IV})-\mathrm{O}-\mathrm{Si}$ bonding motif in C-A-S-H. ${ }^{34,102}$ Detailed investigations have shown that the silicate of this motif prefers a pairing position and is therefore also bonded to a pairing silicate in the principle chain layers. ${ }^{31,33,34,36}$ They are thus labeled $\mathrm{Q}^{(2 \mathrm{p}, 1 \mathrm{Al}(\mathrm{IV}))}$ species, as shown in Figure 1. This places the $\mathrm{Al}(\mathrm{IV})$ in a bridging site, as assumed in our extension of the brick model.

A second, weaker correlation involving the C-A-S-H Al(VI) signal at $5 \mathrm{ppm}$ is the correlation of primary interest. This signal is observed to correlate predominantly to silicates with chemical shifts around $-77 \mathrm{ppm}$, significantly lower than that of the $\mathrm{Q}^{(2 \mathrm{p}, 1 \mathrm{Al}(\mathrm{IV}))}$ species. Conventionally, this chemical shift lands solidly in the range of $\mathrm{Q}^{(1)}$ silicate species, which terminate chains. This could indicate a nonbonding association with the ends of silicates chains; however, this would imply that $\mathrm{Al}(\mathrm{VI})$ is located in the interlayer, which our DFT results indicate is unlikely to exist as a stable species. Alternatively, a bonding association to silicate may exist. A consistent deshielding trend is known for a given silicate unit as $\mathrm{AlO}_{4}$ tetrahedra progressively substitute for $\mathrm{SiO}_{4}$ in its covalent bonding network. ${ }^{103}$ Our results can be explained if the magnitude of this effect also depends on the nature of the aluminate coordination. Electrostatically, screening by greater electron density implies that $\mathrm{Al}-\mathrm{O}$ bond lengths in an $\mathrm{AlO}_{6}$ octahedron should be greater than in an $\mathrm{AlO}_{4}$ tetrahedron. This reduces the covalency of the $\mathrm{Al}(\mathrm{VI})-\mathrm{O}$ bond, increasing the covalency of the bridging $\mathrm{Si}-\mathrm{O}$ bonds and allowing them to get slightly shorter relative to the case of $\mathrm{Al}(\mathrm{IV})-\mathrm{O}$ 
bonding. Table 1 shows that such effects are indeed observable in our DFT-optimized structures. A contraction of a $\mathrm{Si}-\mathrm{O}$

Table 1. DFT-Calculated Mean Values of ${ }^{29} \mathrm{Si}$ Isotropic Chemical Shifts and the Bond Lengths of Bridging $\mathrm{Si}-\mathrm{O}$

\begin{tabular}{cccc} 
species & $\delta_{\text {iso }}\left({ }^{29} \mathrm{Si}\right)(\mathrm{ppm})$ & $d_{\mathrm{Al}-\mathrm{OSi}}(\AA)$ & $d_{\mathrm{Si}-\mathrm{OAl}}(\AA)$ \\
$\mathrm{Q}^{(2 \mathrm{p}, 1 \mathrm{Al}(\mathrm{IV}))}$ & $-82.3 \pm 1.0$ & $1.77 \pm 0.02$ & $1.65 \pm 0.01$ \\
$\mathrm{Q}^{(2 \mathrm{p}, 1 \mathrm{Al}(\mathrm{VI}))}$ & $-79.1 \pm 2.6$ & $1.87 \pm 0.04$ & $1.63 \pm 0.01$ \\
\hline
\end{tabular}

bond correlates with an isotropic deshielding of the ${ }^{29} \mathrm{Si}$ nucleus, all else being equal. ${ }^{104,105}$ This argument is similar to that of Mägi et al., who considered the correlation of other electrostatic parameters to ${ }^{29} \mathrm{Si}$ chemical shifts in silicates and whose findings would also suggest the same correlation between $\mathrm{Al}$ coordination and ${ }^{29} \mathrm{Si}$ chemical shift in $\mathrm{Al}-\mathrm{O}-\mathrm{Si}$ bonding motifs. ${ }^{106}$ Consequently, when $\mathrm{Al}(\mathrm{VI})$ is considered in place of a bridging $\mathrm{Al}(\mathrm{IV})$, we expect that the $\mathrm{Q}^{(2 \mathrm{p}, 1 \mathrm{Al}(\mathrm{VI}))}$ species is subject to additional deshielding over $\mathrm{Q}^{(2 \mathrm{p}, 1 \mathrm{Al}(\mathrm{IV}))}$.

To confirm this, we calculated ${ }^{29} \mathrm{Si}$ chemical shifts of the $\mathrm{Q}^{(2 \mathrm{p}, 1 \mathrm{Al})}$ species in the DFT-optimized structures. The results, plotted in Figure 4B, indeed show the existence of the proposed deshielding effect. This confirms our expectations based on electrostatic and $\mathrm{Si}-\mathrm{O}$ bond length $/{ }^{29} \mathrm{Si}$ chemical shift correlations. The mean ${ }^{29} \mathrm{Si}$ chemical shift values we calculate for the $\mathrm{Q}^{(2 \mathrm{p}, 1 \mathrm{Al}(\mathrm{VI}))}$ and $\mathrm{Q}^{(2 \mathrm{p}, 1 \mathrm{Al}(\mathrm{IV}))}$ distributions are -79.1 and $-82.3 \mathrm{ppm}$, respectively. The difference, $+3.2 \mathrm{ppm}$, is precisely the difference between the ${ }^{29} \mathrm{Si}$ chemical shift maxima of the $\mathrm{Al}(\mathrm{VI})$ and $\mathrm{Al}(\mathrm{IV})$ correlation peaks. We analyze a maximum deviation below $3 \mathrm{ppm}$, establishing the significance of the difference. Therefore, we find the ${ }^{27} \mathrm{Al}$ NMR signal previously assigned to a "third aluminate hydrate phase" is most probably assigned to bridging $A l(V I)$ species which behave as network formers in $C-A-S-H$. The existence of the atomic-level correlation, in conjunction with the observation that $\mathrm{Al}(\mathrm{VI})$ correlates most strongly with a distinct silicate site, renders alternative hypotheses such as $\mathrm{Al}(\mathrm{VI})$ intercalation or physisorption unlikely.

As explained in Section 3 of the SI, the bridging $\mathrm{Al}$ (VI) hypothesis is consistent with the previous observations of Andersen et al. ${ }^{32}$ without invoking the existence of a third (calcium) aluminate hydrate phase. Crucially, our new $\left\{{ }^{29} \mathrm{Si}\right\}{ }^{27} \mathrm{Al}$ correlation NMR data are consistent with the bridging $\mathrm{Al}(\mathrm{VI})$ hypothesis, whereas the $\mathrm{TAH}$ hypothesis is not. We conclude that the TAH phase does not exist.

Water-Driven Interconversion of $\mathrm{Al}(\mathrm{IV})$ and $\mathrm{AI}(\mathrm{VI})$ in C-A-S-H. The manifestation of $\mathrm{Al}(\mathrm{VI})$ species in C-A-S-H is exquisitely tied to the state of sample hydration. We propose the following equilibrium reaction for describing the interconversion of $\mathrm{Al}(\mathrm{IV})$ and $\mathrm{Al}(\mathrm{VI})$ species in $\mathrm{C}-\mathrm{A}-\mathrm{S}-\mathrm{H}$ :

$$
\begin{aligned}
& {\left[\mathrm{AlO}_{2}(\mathrm{OH})_{4}\right]^{5-}+\mathrm{Ca}^{2+}} \\
& \quad \rightleftharpoons\left[\mathrm{AlO}_{3} \mathrm{OH}\right]^{4-}+\mathrm{CaOH}^{+}+\mathrm{H}_{2} \mathrm{O}
\end{aligned}
$$

As water departs from the C-A-S-H structure under dehydrating conditions (low humidity, heat, hygroscopic additives), this equilibrium reaction shifts to the right. Using TGA we measured the onset of significant water loss from a CA-S-H sample with $(\mathrm{Al}: \mathrm{Si})_{\mathrm{i}}=0.07$ above $50{ }^{\circ} \mathrm{C}$ (Figure $\mathrm{S} 13$ ), which matches well with the observations of Andersen et al. that the TAH signal is lost at temperatures above $70{ }^{\circ} \mathrm{C} .{ }^{32}$ This scheme also explains why the addition of hygroscopic glycerol eliminates the $5 \mathrm{ppm} \mathrm{Al}(\mathrm{VI})$ signal from the ${ }^{27} \mathrm{Al} \mathrm{NMR}$ spectrum (Figure S11). No matter the coordination state of aluminum, two bridging oxygen atoms anchor the aluminate to the silicate framework, leaving the defective tobermorite structure intact.

Our DFT-optimized structures support this chemistry, as illustrated in Figure 5. Here, the environment of interlayer

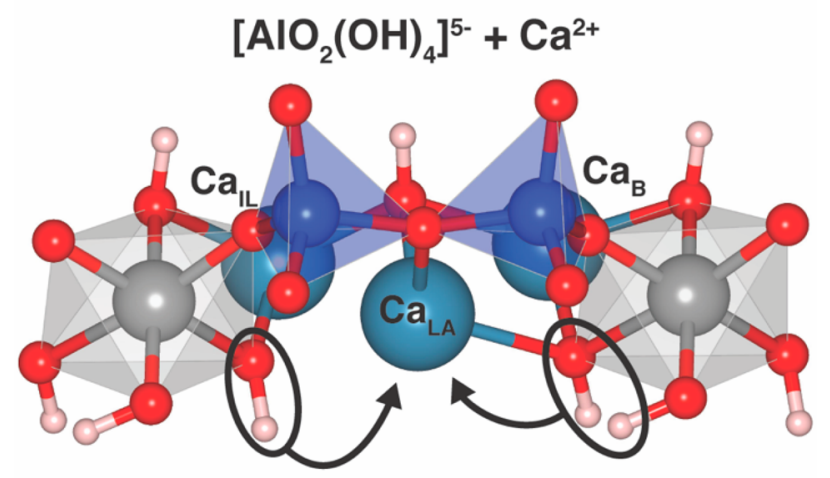

$$
\left[\mathrm{AlO}_{3} \mathrm{OH}\right]^{4-}+\mathrm{CaOH}^{+}+\mathrm{H}_{2} \mathrm{O}
$$

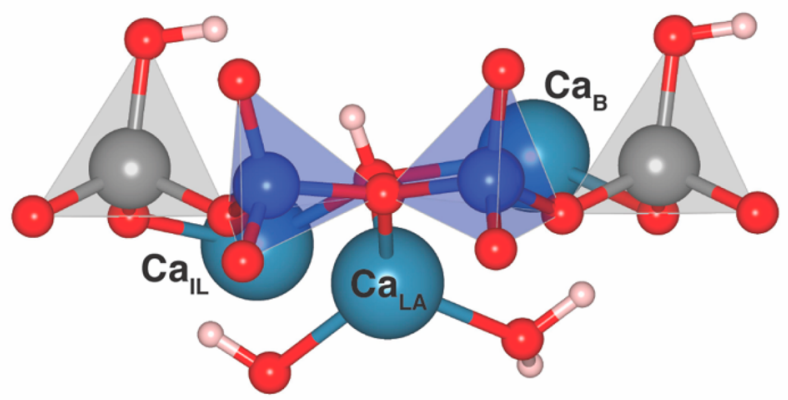

Figure 5. Calcium coordination environment between $\mathrm{Al}(\mathrm{VI})$ (top) and $\mathrm{Al}(\mathrm{IV})$ (bottom) bridging aluminate species in DFT-optimized structures with $\mathrm{Ca}: \mathrm{Si}=1.75$ and $\mathrm{H}_{2} \mathrm{O}: \mathrm{Si}=1.625$. The calcium-labeled $\mathrm{Ca}_{\mathrm{LA}}$ exhibits greater Lewis acidity when flanked by $\mathrm{Al}(\mathrm{IV})$. The $\left[\mathrm{AlO}_{2}(\mathrm{OH})_{4}\right]^{5-}$ complex can be considered a donor of the circled $\mathrm{OH}^{-}$and $\mathrm{H}_{2} \mathrm{O}$ ligands to $\mathrm{Ca}_{\mathrm{LA}}$, leading to $\left[\mathrm{AlO}_{3} \mathrm{OH}\right]^{4-}$. A Ca-O bond length cutoff of $2.5 \AA$ was used, leading to effective $\mathrm{Ca}_{\mathrm{LA}}$ coordination numbers of three (top) and four (bottom).

calcium in the vicinity of bridging aluminates is shown for two structures with high $\mathrm{Ca}: \mathrm{Si}$ and $\mathrm{H}_{2} \mathrm{O}: \mathrm{Si}$ ratios of 1.75 and 1.625 , respectively. While overall the calcium environments in both structures are similar, one particular calcium ion, labeled $\mathrm{Ca}_{\mathrm{LA}}$ in Figure 5, is an exception. For the structure containing $\mathrm{Al}(\mathrm{VI})$, the $\mathrm{Ca}_{\mathrm{LA}}$ appears to bridge the two $\left[\mathrm{AlO}_{2}(\mathrm{OH})_{4}\right]^{5-}$ complexes, with $d(\mathrm{Ca}, \mathrm{Al})=3.63$ and $3.73 \AA$. We could identify this as an ionic interaction between $\left[\mathrm{AlO}_{2}(\mathrm{OH})_{4}\right]^{5-}$ and $\mathrm{Ca}^{2+}$, suggesting the left-hand side of reaction 1 . On the other hand, the $\left[\mathrm{AlO}_{3} \mathrm{OH}\right]^{4-}$ tetrahedra of the $\mathrm{Al}(\mathrm{IV})$ structure show no such bridging configuration with $\mathrm{Ca}_{\mathrm{LA}}$, with $d(\mathrm{Ca}, \mathrm{Al})=3.93$ and $4.15 \AA$, due to weaker electrostatic interactions of the cation with the lower effective negative charge of the aluminate complex. Instead, $\mathrm{Ca}_{\mathrm{LA}}$ acts as a Lewis acid as new interactions with $\mathrm{OH}^{-}$and $\mathrm{H}_{2} \mathrm{O}$ are observed. This suggests the right-hand side of reaction 1 . In these structures, $\left[\mathrm{AlO}_{2}(\mathrm{OH})_{4}\right]^{5-}$ and $\mathrm{Ca}_{\mathrm{LA}}$ occur in a 1:1 ratio, such that one $\mathrm{OH}^{-}$and $\mathrm{H}_{2} \mathrm{O}$ ligand can be supplied to $\mathrm{Ca}_{\mathrm{LA}}$ by every $\left[\mathrm{AlO}_{2}(\mathrm{OH})_{4}\right]^{5-}$ when transforming into $\left[\mathrm{AlO}_{3} \mathrm{OH}\right]^{4-}$. This connects the proposed reaction 1 to our DFT results and reveals crucial roles of 
calcium and water in controlling aluminosilicate chain structure in C-A-S-H.

Though our DFT calculations find a lower overall energy for the $\mathrm{Al}(\mathrm{VI})$ environment $(\Delta E=-0.3 \mathrm{eV})$, both structures are stable, i.e., both exist in local energy minima along their respective reaction coordinates. Reaction 1 is expected to have a negative free energy in water-deficient conditions.

Representative Structure of C-A-S-H. We have constructed a representative bulk C-A-S-H structure that has $\mathrm{Al}(\mathrm{IV}), \mathrm{Al}(\mathrm{V})$, and $\mathrm{Al}(\mathrm{VI})$ at the bridging positions as determined by our NMR results. The structure is created from the juxtaposition of different C-S-H or C-A-S-H structural units based upon defective $14 \AA$ tobermorite ("bricks") measuring 4 by 4 by 2 units along the $\vec{a}, \vec{b}$, and $\vec{c}$ directions, respectively. The structure is equilibrated using classical molecular dynamics simulations. In these simulations bridging $\mathrm{Al}(\mathrm{VI})$ in the bulk structure is stable out to $2 \mathrm{~ns}$ at $300 \mathrm{~K}$ and $1 \mathrm{~atm}$, showing that it retains the essential features inferred from our analysis of the individual structural units.

The selection of bricks was made to ensure the bulk structure adhered to known experimental constraints. The $\mathrm{Ca}: \mathrm{Si}, \mathrm{Al}: \mathrm{Si}$, and $\mathrm{H}_{2} \mathrm{O}: \mathrm{Si}$ ratios of the structure are $1.7,0.05$, and 1.9 , respectively. The mean aluminosilicate chain length is 3.17, comprising dimers (disilicate units), pentamers, and octamers. Dai et al. observed a mean chain length of 3.21 for C-A-S-H having Al:Si $=0.05$ from a 28 -day hydrated white Portland cement; ${ }^{37}$ however, the mean chain length was calculated considering only the incorporation of $\mathrm{Al}(\mathrm{IV})$ at the bridging site. Thomas et al. observed that $23 \%$ of the charge of calcium C-S-H is balanced by hydroxyl groups. ${ }^{107}$ In our structure this value is about $22 \%$.

The percentages of $\mathrm{Al}(\mathrm{IV}), \mathrm{Al}(\mathrm{V})$, and $\mathrm{Al}(\mathrm{VI})$ in this structure after equilibration are $0 \%, 25 \%$, and $75 \%$, respectively summing to an average coordination number of 5.75. In the initial structure all aluminum exists in tetrahedral coordination. During structural relaxation with a nonreactive force field, the increase in aluminum coordination number was directly related to the local availability of hydroxide species. Bridging $\left[\mathrm{AlO}_{3} \mathrm{OH}\right]^{4-}$ configurations would remain in 4-fold coordination or convert to bridging $\mathrm{Al}(\mathrm{V})$ or $\mathrm{Al}(\mathrm{VI})$ geometry if $\mathrm{OH}^{-}$ was available nearby. Those with the initial configuration of $\left[\mathrm{AlO}_{2}(\mathrm{OH})_{2}\right]^{3-}$ and locally available $\mathrm{OH}^{-}$always converted to a higher coordination, in line with our DFT calculations of aluminate stability in C-A-S-H. An image of the relaxed bulk structure is provided in Figure 6.

We note that other studies have proposed alternative ways in which $\mathrm{Al}(\mathrm{VI})$ may be stabilized in C-A-S-H. Qomi et al. ${ }^{44}$ considered the substitution of $\mathrm{Ca}_{\mathrm{IL}}$ by aluminum in $\mathrm{C}-\mathrm{S}-\mathrm{H}$ structures based upon $11 \AA$ tobermorite-based C-S-H structures using $\mathrm{MD}$ simulations and found that octahedrally coordinated aluminum could exhibit energetically favorable bonding interactions with silica chains provided at least one water molecule ${ }^{44,108}$ enters the first coordination shell. Our results on $\left[\mathrm{AlO}_{2}(\mathrm{OH})_{(4-x)}\left(\mathrm{H}_{2} \mathrm{O}\right)_{x}\right]^{(5-x)-}, x=1,2$, imply that the $\left|C_{\mathrm{q}}\right|$ values will be much larger than those observed at 5 ppm in the ${ }^{27} \mathrm{Al} \mathrm{NMR}$. Furthermore, as mentioned above, we find that interlayer $\mathrm{Al}(\mathrm{VI})$ aluminates are unstable compared to bridging aluminates and relax into five-fold coordination in our DFT calculations with a higher energy penalty. Qomi et al. concluded that their observation is consistent with experimental ${ }^{27} \mathrm{Al}$ NMR results of Rawal et al. ${ }^{87}$ on white Portland cement, who speculated that a broad distribution of ${ }^{27} \mathrm{Al}$

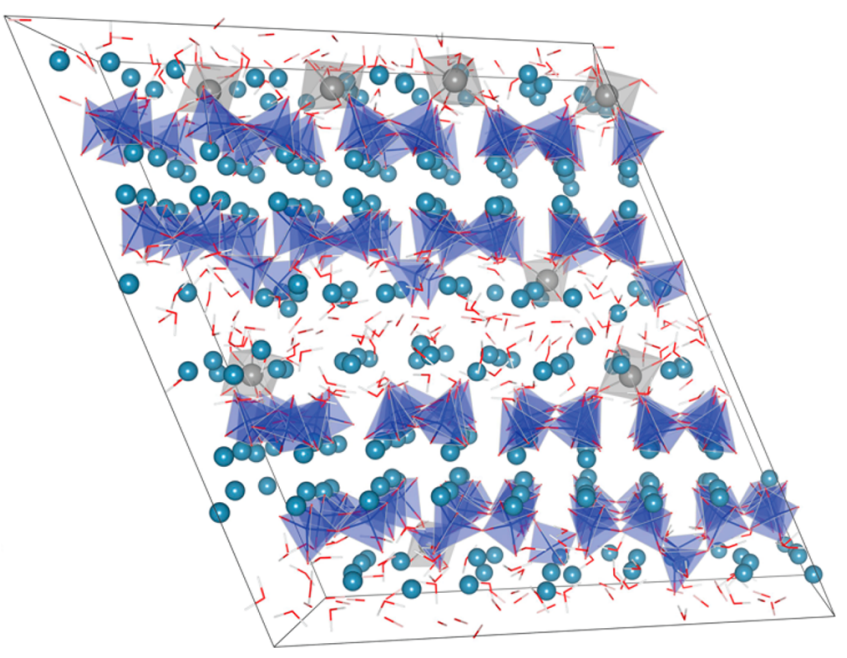

Figure 6. Representative $\mathrm{C}-\mathrm{A}-\mathrm{S}-\mathrm{H}$ bulk structure with the stoichiometry $(\mathrm{CaO})_{1.7}\left(\mathrm{Al}_{2} \mathrm{O}_{3}\right)_{0.05} \mathrm{SiO}_{2}\left(\mathrm{H}_{2} \mathrm{O}\right)_{1.9}$.

signals centered around $7 \mathrm{ppm}$ could be assigned to $\mathrm{Al}(\mathrm{VI})$ species possessing water ligands in $\mathrm{C}-\mathrm{A}-\mathrm{S}-\mathrm{H}$ (in addition to the usual TAH assignment for a species at $5 \mathrm{ppm}$ ). No such signal is observed in our C-A-S-H samples prepared by rapid precipitation. We suggest that the alternative assignment of the $7 \mathrm{ppm}$ signal given by Rawal et al. in relation to their results on gray oilwell cement, to an aluminoferrite phase from which the ${ }^{27} \mathrm{Al}$ NMR signal is paramagnetically broadened, is more likely, especially in light of the fact that they estimated $\sim 20 \%$ of their ${ }^{27} \mathrm{Al}$ NMR signal was bleached due to residual $\mathrm{Fe}^{3+}$ in their hydrated white Portland cement sample.

Additionally, Qomi et al. ${ }^{44}$ observed that six-coordinate aluminates could serve to cross-link four $Q^{(1)}$ species across the interlayer. A decreased separation between the principal layers, i.e., a smaller interlayer distance less than $10 \AA$, is a necessary consequence of this bonding motif, but the opposite is observed experimentally. ${ }^{100,109}$ The interlayer distance of our MD relaxed (for $\sim 1.4 \mathrm{~ns}$ at $300 \mathrm{~K}$ ) bulk C-A-S-H structure described above is $13.5 \AA$. Renaudin et al. ${ }^{109}$ reported an interlayer distance in the range of $14.5 \AA$ for a Ca:Si ratio $<1.4$, whereas l'Hôpital et al. ${ }^{100}$ reported a value in the range of $12 \AA$ for synthetic C-A-S-H samples with a Ca:Si ratio of 1.0. It is to be noted, however, that drying the samples can significantly affect the interlayer distance measurement. ${ }^{110}$ There is no other experimental evidence for cross-linking in C-(A)-S-H produced in blended cement, and the observation of these moieties in the molecular modeling of Qomi et al. is probably a result of using 11 Å tobermorite, which possesses cross-linking silicates, as the basis of the modeled structural framework. Therefore, we conclude that such cross-linking $\mathrm{Al}(\mathrm{VI})$ species are unlikely to occur in most C-A-S-H formulations.

\section{CONCLUSIONS}

By combining DFT computational methods using the C-S-H brick model ${ }^{29}$ with DNP-enhanced solid-state NMR experiments, particularly $\left\{{ }^{29} \mathrm{Si}\right\}{ }^{27} \mathrm{Al}$ correlation experiments, we are able to determine the atomic-level structure of cementitious $(\mathrm{Ca}: \mathrm{Si} \geq 1.0) \mathrm{C}-\mathrm{A}-\mathrm{S}-\mathrm{H}$ at a new level of detail, as presented in Figure 6.

Energetically stable aluminates are incorporated as bridging sites into the silicate chain framework. Bridging four-, five-, and six-coordinate aluminates are all present. Tetrahedral Al(IV) 
species are favored at low $\mathrm{Ca}: \mathrm{Si}$ ratios, but at $\mathrm{Ca}: \mathrm{Si} \geq 1.2$, $\mathrm{Al}(\mathrm{V})$ and octahedral $\mathrm{Al}(\mathrm{VI})$ species overtake $\mathrm{Al}(\mathrm{IV})$ species in overall stability, provided that $\mathrm{OH}^{-}$ions are available as ligands. Hydroxyl availability increases with additional water and interlayer calcium ions, making bridging $\left[\mathrm{AlO}_{2}(\mathrm{OH})_{4}\right]^{5-}$ the most energetically favorable species at high $\mathrm{Ca}: \mathrm{Si}$ and $\mathrm{H}_{2} \mathrm{O}: \mathrm{Si}$ and low $\mathrm{Al}: \mathrm{Si}$ ratios. A consequence of the bridging $\mathrm{Al}(\mathrm{VI})$ theory is a calcium-enabled, water-driven interconversion chemistry between bridging $\mathrm{Al}(\mathrm{IV})$ and $\mathrm{Al}(\mathrm{VI})$ species, suggesting calcium and water play a direct role in controlling the aluminosilicate chain structure in C-A-S-H.

DNP-enhanced $1 \mathrm{D}^{27} \mathrm{Al} \mathrm{CP}$ MAS NMR of nearly pure C-A$\mathrm{S}-\mathrm{H}$ with a low $\mathrm{Al}: \mathrm{Si}$ ratio of around 0.04 resolves signals of $\mathrm{Al}(\mathrm{IV}), \mathrm{Al}(\mathrm{V})$, and $\mathrm{Al}(\mathrm{VI})$, dominated by the $\mathrm{Al}(\mathrm{VI})$ signal at 5 ppm that is conventionally assigned to a TAH phase. DFT calculations of ${ }^{27} \mathrm{Al} \mathrm{NMR}$ parameters support the assignment of $5 \mathrm{ppm}{ }^{27} \mathrm{Al} \mathrm{NMR}$ signal to $\left[\mathrm{AlO}_{2}(\mathrm{OH})_{4}\right]^{5-}$ moieties. At low $\mathrm{Al}: \mathrm{Si}$ ratios, these signals survive filtering by dipolar recoupled ${ }^{29} \mathrm{Si}$ magnetization transfer to ${ }^{27} \mathrm{Al}$, indicating that they are directly bonded to silicates. From this, and corresponding 2D ${ }^{27} \mathrm{Al}-{ }^{29} \mathrm{Si}$ DNP-enhanced correlation spectra, we conclude each of these aluminate species, including the signal at $5 \mathrm{ppm}$, exists as part of the C-A-S-H structure. This finding is consistent with the bridging $\mathrm{Al}(\mathrm{VI})$ hypothesis. We conclude that the TAH phase does not exist.

\section{ASSOCIATED CONTENT}

\section{SI Supporting Information}

The Supporting Information is available free of charge at https://pubs.acs.org/doi/10.1021/jacs.0c02988.

Supplementary text cataloging the DFT structures, additional structure visualization, details regarding nanomechanical properties, NMR parameters, MD calculations, and additional NMR, TGA, and TEM characterization (PDF)

Coordinate files for all C-S-H and C-A-S-H structures (ZIP)

\section{AUTHOR INFORMATION}

\section{Corresponding Authors}

Aslam Kunhi Mohamed - Laboratory of Construction Materials, Institut des Materiaux, Ecole Polytechnique Féderale de Lausanne (EPFL), CH-1015 Lausanne, Switzerland; Institute for Building Materials, Department of Civil, Environmental and Geomatic Engineering, ETH Zürich, $\mathrm{CH}$ 8093 Zürich, Switzerland; 이이이.org/0000-0001-66809599; Email: aslam.kunhimohamed@epfl.ch

Lyndon Emsley - Institut des Sciences et Ingénierie Chimiques, Ecole Polytechnique Féderale de Lausanne (EPFL), CH-1015 Lausanne, Switzerland; 이이이.org/0000-0003-1360-2572; Email: lyndon.emsley@epfl.ch

\section{Authors}

Pinelopi Moutzouri - Institut des Sciences et Ingénierie Chimiques, Ecole Polytechnique Féderale de Lausanne (EPFL), CH-1015 Lausanne, Switzerland

Pierrick Berruyer - Institut des Sciences et Ingénierie Chimiques, Ecole Polytechnique Féderale de Lausanne (EPFL), CH-1015 Lausanne, Switzerland; 이이. orid.org/0000-0003-1783-6034

Brennan J. Walder - Institut des Sciences et Ingénierie Chimiques, Ecole Polytechnique Féderale de Lausanne (EPFL), $\mathrm{CH}-1015$ Lausanne, Switzerland
Jirawan Siramanont - Laboratory of Construction Materials, Institut des Materiaux, Ecole Polytechnique Féderale de Lausanne (EPFL), CH-1015 Lausanne, Switzerland; SCG CEMENT Co., Ltd., Saraburi 18260, Thailand

Maya Harris - Laboratory of Construction Materials, Institut des Matériaux, Ecole Polytechnique Féderale de Lausanne (EPFL), CH-1015 Lausanne, Switzerland

Mattia Negroni - Institut des Sciences et Ingénierie Chimiques, Ecole Polytechnique Féderale de Lausanne (EPFL), CH-1015 Lausanne, Switzerland

Sandra C. Galmarini - Building Energy Materials and Components, EMPA, CH-8600 Dübendorf, Switzerland

Stephen C. Parker - Computational Solid State Chemistry Group, Department of Chemistry, University of Bath, Bath BA2 7AY, U.K.

Karen L. Scrivener - Laboratory of Construction Materials, Institut des Materiaux, Ecole Polytechnique Féderale de Lausanne (EPFL), CH-1015 Lausanne, Switzerland

Paul Bowen - Laboratory of Construction Materials, Institut des Materiaux, Ecole Polytechnique Féderale de Lausanne (EPFL), CH-1015 Lausanne, Switzerland

Complete contact information is available at:

https://pubs.acs.org/10.1021/jacs.0c02988

\section{Notes}

The authors declare no competing financial interest. The raw NMR data can be found at DOI: $10.5281 /$ zenodo. 3855010 .

\section{ACKNOWLEDGMENTS}

We thank the Swiss National Foundation for financing this work through grant nos. 153044 and 200020_178860. The authors would like to thank the SCITAS at EPFL for giving access to HPC computing resources for the calculations. Advice from Dr. Albert Hofstetter regarding DFT calculations of NMR parameters is gratefully acknowledged. A.K.M. would like to thank Prof. Robert Flatt from ETH Zürich for the support and fruitful discussions, and Dr. Ulrich Aschauer from the University of Bern for helpful discussions.

\section{REFERENCES}

(1) Lothenbach, B.; Scrivener, K.; Hooton, R. D. Supplementary Cementitious Materials. Cem. Concr. Res. 2011, 41 (12), 1244-1256.

(2) Monteiro, P. J. M.; Miller, S. A.; Horvath, A. Towards Sustainable Concrete. Nat. Mater. 2017, 16 (7), 698-699.

(3) Scrivener, K.; Martirena, F.; Bishnoi, S.; Maity, S. Calcined Clay Limestone Cements (LC3). Cem. Concr. Res. 2018, 114, 49-56.

(4) Scrivener, K. L.; Gartner, E. M. Eco-Efficient Cements: Potential Economically Viable Solutions for a Low-CO2 Cement-Based Materials Industry. Cem. Concr. Res. 2018, 114, 2-26.

(5) Damineli, B. L.; Quattrone, M.; Pileggi, R. G. Fillers in Cementitious Materials - Experience, Recent Advances and Future Potential. Cem. Concr. Res. 2018, 114, 65-78.

(6) Allen, A. J.; Thomas, J. J.; Jennings, H. M. Composition and Density of Nanoscale Calcium-Silicate-Hydrate in Cement. Nat. Mater. 2007, 6 (4), 311-316.

(7) Nonat, A. The Structure and Stoichiometry of C-S-H. Cem. Concr. Res. 2004, 34 (9), 1521-1528.

(8) Taylor, H. F. W. Hydrated Calcium Silicates. Part I. Compound Formation at Ordinary Temperatures. J. Chem. Soc. 1950, 36823690.

(9) Taylor, H. F. W. W. Proposed Structure for Calcium Silicate Hydrate Gel. J. Am. Ceram. Soc. 1986, 69 (6), 464-467. 
(10) Skinner, L. B.; Chae, S. R.; Benmore, C. J.; Wenk, H. R.; Monteiro, P. J. M. Nanostructure of Calcium Silicate Hydrates in Cements. Phys. Rev. Lett. 2010, 104 (19), 195502.

(11) Goñi, S.; Puertas, F.; Hernández, M. S.; Palacios, M.; Guerrero, A.; Dolado, J. S.; Zanga, B.; Baroni, F. Quantitative Study of Hydration of $\mathrm{C}_{3} \mathrm{~S}$ and $\mathrm{C}_{2} \mathrm{~S}$ by Thermal Analysis. J. Therm. Anal. Calorim. 2010, 102 (3), 965-973.

(12) USGS. Mineral Commodity Summaries 2019, https://www. usgs.gov/centers/nmic/cement-statistics-and-information (accessed Oct 15, 2019) DOI: 10.1007/978-3-540-47108-0-4.

(13) Targan, C.; Olgun, a.; Erdogan, Y.; Sevinc, V. Effects of Supplementary Cementing Materials on the Properties of Cement and Concrete. Cem. Concr. Res. 2002, 32 (10), 1551-1558.

(14) Berodier, E.; Scrivener, K. Evolution of Pore Structure in Blended Systems. Cem. Concr. Res. 2015, 73, 25-35.

(15) Schöler, A.; Lothenbach, B.; Winnefeld, F.; Haha, M. B.; Zajac, M.; Ludwig, H. M. Early Hydration of SCM-Blended Portland Cements: A Pore Solution and Isothermal Calorimetry Study. Cem. Concr. Res. 2017, 93, 71-82.

(16) Antoni, M.; Rossen, J.; Martirena, F.; Scrivener, K. Cement Substitution by a Combination of Metakaolin and Limestone. Cem. Concr. Res. 2012, 42 (12), 1579-1589.

(17) Richardson, I. The Nature of C-S-H in Hardened Cements. Cem. Concr. Res. 1999, 29 (8), 1131-1147.

(18) Muller, A. C. A.; Scrivener, K. L.; Gajewicz, A. M.; McDonald, P. J. Densification of C-S-H Measured by ${ }^{1} \mathrm{H}$ NMR Relaxometry. J. Phys. Chem. C 2013, 117 (1), 403-412.

(19) Richardson, I. G. G. Tobermorite/Jennite- and Tobermorite/ Calcium Hydroxide-Based Models for the Structure of C-S-H: Applicability to Hardened Pastes of Tricalcium Silicate, [Beta]Dicalcium Silicate, Portland Cement, and Blends of Portland Cement with Blast-Furnace Slag, Met. Cem. Concr. Res. 2004, 34 (9), 17331777.

(20) Kumar, A.; Walder, B. J.; Kunhi Mohamed, A.; Hofstetter, A.; Srinivasan, B.; Rossini, A. J.; Scrivener, K.; Emsley, L.; Bowen, P. The Atomic-Level Structure of Cementitious Calcium Silicate Hydrate. J. Phys. Chem. C 2017, 121 (32), 17188-17196.

(21) Abdolhosseini Qomi, M. J.; Krakowiak, K. J.; Bauchy, M.; Stewart, K. L.; Shahsavari, R.; Jagannathan, D.; Brommer, D. B.; Baronnet, a; Buehler, M. J.; Yip, S.; et al. Combinatorial Molecular Optimization of Cement Hydrates. Nat. Commun. 2014, 5, 4960.

(22) Cong, X.; Kirkpatrick, R. J. ${ }^{29}$ Si MAS NMR Study of the Structure of Calcium Silicate Hydrate. Adv. Cem. Based Mater. 1996, 3 (3-4), 144-156.

(23) Brunet, F.; Bertani, P.; Charpentier, T.; Nonat, A.; Virlet, J. Application of ${ }^{29} \mathrm{Si}$ Homonuclear and ${ }^{1} \mathrm{H}-{ }^{29} \mathrm{Si}$ Heteronuclear NMR Correlation to Structural Studies of Calcium Silicate Hydrates. J. Phys. Chem. B 2004, 108 (40), 15494-15502.

(24) Pustovgar, E.; Sangodkar, R. P.; Andreev, A. S.; Palacios, M.; Chmelka, B. F.; Flatt, R. J.; d'Espinose de Lacaillerie, J.-B. Understanding Silicate Hydration from Quantitative Analyses of Hydrating Tricalcium Silicates. Nat. Commun. 2016, 7, 10952.

(25) Richardson, I. G. The Calcium Silicate Hydrates. Cem. Concr. Res. 2008, 38 (2), 137-158.

(26) Grangeon, S.; Fernandez-Martinez, A.; Baronnet, A.; Marty, N.; Poulain, A.; Elkaïm, E.; Roosz, C.; Gaboreau, S.; Henocq, P.; Claret, F. Quantitative X-Ray Pair Distribution Function Analysis of Nanocrystalline Calcium Silicate Hydrates: A Contribution to the Understanding of Cement Chemistry. J. Appl. Crystallogr. 2017, 50 (1), 14-21.

(27) Pellenq, R. J.-M. M.; Kushima, A.; Shahsavari, R.; Van Vliet, K. J.; Buehler, M. J.; Yip, S.; Ulm, F.-J. J. A Realistic Molecular Model of Cement Hydrates. Proc. Natl. Acad. Sci. U. S. A. 2009, 106 (38), 16102-16107.

(28) Kovačević, G.; Persson, B.; Nicoleau, L.; Nonat, A.; Veryazov, V. Atomistic Modeling of Crystal Structure of Ca1.67SiHx. Cem. Concr. Res. 2015, 67, 197-203.
(29) Kunhi Mohamed, A.; Parker, S. C.; Bowen, P.; Galmarini, S. An Atomistic Building Block Description of C-S-H - Towards a Realistic C-S-H Model. Cem. Concr. Res. 2018, 107, 221-235.

(30) Faucon, P.; Delagrave, A.; Richet, C.; Marchand, J. M.; Zanni, $\mathrm{H}$. Aluminum Incorporation in Calcium Silicate Hydrates $(\mathrm{C}-\mathrm{S}-\mathrm{H})$ Depending on Their Ca/Si Ratio. J. Phys. Chem. B 1999, 103 (37), $7796-7802$

(31) Andersen, M. D.; Jakobsen, H. J.; Skibsted, J. Incorporation of Aluminum in the Calcium Silicate Hydrate $(\mathrm{C}-\mathrm{S}-\mathrm{H})$ of Hydrated Portland Cements: A High-Field ${ }^{27} \mathrm{Al}$ and ${ }^{29} \mathrm{Si}$ MAS NMR Investigation. Inorg. Chem. 2003, 42 (7), 2280-2287.

(32) Andersen, M. D.; Jakobsen, H. J.; Skibsted, J. A New Aluminium-Hydrate Species in Hydrated Portland Cements Characterized by ${ }^{27} \mathrm{Al}$ and ${ }^{29} \mathrm{Si}$ MAS NMR Spectroscopy. Cem. Concr. Res. 2006, 36 (1), 3-17.

(33) Richardson, I. G. G.; Groves, G. W. W. The Incorporation of Minor and Trace Elements into Calcium Silicate Hydrate (CSH) Gel in Hardened Cement Pastes. Cem. Concr. Res. 1993, 23 (1), 131-138.

(34) Richardson, I. G.; Brough, A. R.; Brydson, R.; Groves, G. W.; Dobson, C. M. Location of Aluminum in Substituted Calcium Silicate Hydrate (C-S-H) Gels as Determined by ${ }^{29} \mathrm{Si}$ and ${ }^{27} \mathrm{Al} \mathrm{NMR}$ and EELS. J. Am. Ceram. Soc. 1993, 76 (9), 2285-2288.

(35) Manzano, H.; Dolado, J. S.; Ayuela, A. Aluminum Incorporation to Dreierketten Silicate Chains. J. Phys. Chem. B 2009, 113 (9), 2832-2839.

(36) Pegado, L.; Labbez, C.; Churakov, S. V. Mechanism of Aluminium Incorporation into $\mathrm{C}-\mathrm{S}-\mathrm{H}$ from $\mathrm{Ab}$ Initio Calculations. J. Mater. Chem. A 2014, 2 (10), 3477.

(37) Dai, Z.; Tran, T. T.; Skibsted, J. Aluminum Incorporation in the C-S-H Phase of White Portland Cement-Metakaolin Blends Studied by ${ }^{27} \mathrm{Al}$ and ${ }^{29} \mathrm{Si}$ MAS NMR Spectroscopy. J. Am. Ceram. Soc. 2014, 97 (8), 2662-2671.

(38) Sun, G. K.; Young, J. F.; Kirkpatrick, R. J. The Role of Al in CS-H: NMR, XRD, and Compositional Results for Precipitated Samples. Cem. Concr. Res. 2006, 36 (1), 18-29.

(39) Pardal, X.; Brunet, F.; Charpentier, T.; Pochard, I.; Nonat, A. ${ }^{27} \mathrm{Al}$ and ${ }^{29} \mathrm{Si}$ Solid-State NMR Characterization of CalciumAluminosilicate-Hydrate. Inorg. Chem. 2012, 51 (3), 1827-1836.

(40) Pustovgar, E.; Mishra, R. K.; Palacios, M.; d'Espinose de Lacaillerie, J. B.; Matschei, T.; Andreev, A. S.; Heinz, H.; Verel, R.; Flatt, R. J. Influence of Aluminates on the Hydration Kinetics of Tricalcium Silicate. Cem. Concr. Res. 2017, 100 (June), 245-262.

(41) Renaudin, G.; Russias, J.; Leroux, F.; Cau-dit-Coumes, C.; Frizon, F. Structural Characterization of C-S-H and C-A-S-H Samples-Part II: Local Environment Investigated by Spectroscopic Analyses. J. Solid State Chem. 2009, 182 (12), 3320-3329.

(42) Stade, H.; Müller, D. On the Coordination of Al in IllCrystallized C-S-H Phases Formed by Hydration of Tricalcium Silicate and by Precipitation Reactions at Ambient Temperature. Cem. Concr. Res. 1987, 17 (4), 553-561.

(43) L'Hôpital, E.; Lothenbach, B.; Kulik, D. A.; Scrivener, K. Influence of Calcium to Silica Ratio on Aluminium Uptake in Calcium Silicate Hydrate. Cem. Concr. Res. 2016, 85, 111-121.

(44) Abdolhosseini Qomi, M. J.; Ulm, F.-J.; Pellenq, R. J. M. Evidence on the Dual Nature of Aluminum in the Calcium-SilicateHydrates Based on Atomistic SimulationsJ. Am. Ceram. Soc.2012, 95, 3 DOI: $10.1111 /$ j.1551-2916.2011.05058.x.

(45) Hall, D. A.; Maus, D. C.; Gerfen, G. J.; Inati, S. J.; Becerra, L. R.; Dahlquist, F. W.; Griffin, R. G. Polarization-Enhanced NMR Spectroscopy of Biomolecules in Frozen Solution. Science (Washington, DC, U. S.) 1997, 276 (5314), 930-932.

(46) Maly, T.; Debelouchina, G. T.; Bajaj, V. S.; Hu, K.-N.; Joo, C.G.; Mak-Jurkauskas, M. L.; Sirigiri, J. R.; van der Wel, P. C. A.; Herzfeld, J.; Temkin, R. J.; et al. Dynamic Nuclear Polarization at High Magnetic Fields. J. Chem. Phys. 2008, 128 (5), 052211.

(47) Ni, Q. Z.; Daviso, E.; Can, T. V.; Markhasin, E.; Jawla, S. K.; Swager, T. M.; Temkin, R. J.; Herzfeld, J.; Griffin, R. G. High Frequency Dynamic Nuclear Polarization. Acc. Chem. Res. 2013, 46 (9), 1933-1941. 
(48) Rossini, A. J.; Zagdoun, A.; Lelli, M.; Lesage, A.; Copéret, C.; Emsley, L. Dynamic Nuclear Polarization Surface Enhanced NMR Spectroscopy. Acc. Chem. Res. 2013, 46 (9), 1942-1951.

(49) Lesage, A.; Lelli, M.; Gajan, D.; Caporini, M. A.; Vitzthum, V.; Miéville, P.; Alauzun, J.; Roussey, A.; Thieuleux, C.; Mehdi, A.; et al. Surface Enhanced NMR Spectroscopy by Dynamic Nuclear Polarization. J. Am. Chem. Soc. 2010, 132 (44), 15459-15461.

(50) Lelli, M.; Gajan, D.; Lesage, A.; Caporini, M. A.; Vitzthum, V.; Miéville, P.; Héroguel, F.; Rascón, F.; Roussey, A.; Thieuleux, C.; et al. Fast Characterization of Functionalized Silica Materials by Silicon-29 Surface-Enhanced NMR Spectroscopy Using Dynamic Nuclear Polarization. J. Am. Chem. Soc. 2011, 133 (7), 2104-2107.

(51) Lafon, O.; Thankamony, A. S. L.; Kobayashi, T.; Carnevale, D.; Vitzthum, V.; Slowing, I. I.; Kandel, K.; Vezin, H.; Amoureux, J.-P.; Bodenhausen, G.; et al. Mesoporous Silica Nanoparticles Loaded with Surfactant: Low Temperature Magic Angle Spinning ${ }^{13} \mathrm{C}$ and ${ }^{29} \mathrm{Si}$ NMR Enhanced by Dynamic Nuclear Polarization. J. Phys. Chem. C 2013, 117 (3), 1375-1382.

(52) Perras, F. A.; Kobayashi, T.; Pruski, M. Natural Abundance ${ }^{17}$ O DNP Two-Dimensional and Surface-Enhanced NMR Spectroscopy. J. Am. Chem. Soc. 2015, 137 (26), 8336-8339.

(53) Perras, F. A.; Chaudhary, U.; Slowing, I. I.; Pruski, M. Probing Surface Hydrogen Bonding and Dynamics by Natural Abundance, Multidimensional, ${ }^{17}$ O DNP-NMR Spectroscopy. J. Phys. Chem. C 2016, 120 (21), 11535-11544.

(54) Berruyer, P.; Lelli, M.; Conley, M. P.; Silverio, D. L.; Widdifield, C. M.; Siddiqi, G.; Gajan, D.; Lesage, A.; Copéret, C.; Emsley, L. Three-Dimensional Structure Determination of Surface Sites. J. Am. Chem. Soc. 2017, 139 (2), 849-855.

(55) Smeets, S.; Berkson, Z. J.; Xie, D.; Zones, S. I.; Wan, W.; Zou, X.; Hsieh, M.-F.; Chmelka, B. F.; McCusker, L. B.; Baerlocher, C. Well-Defined Silanols in the Structure of the Calcined High-Silica Zeolite SSZ-70: New Understanding of a Successful Catalytic Material. J. Am. Chem. Soc. 2017, 139 (46), 16803-16812.

(56) Valla, M.; Rossini, A. J.; Caillot, M.; Chizallet, C.; Raybaud, P.; Digne, M.; Chaumonnot, A.; Lesage, A.; Emsley, L.; van Bokhoven, J. A.; et al. Atomic Description of the Interface between Silica and Alumina in Aluminosilicates through Dynamic Nuclear Polarization Surface-Enhanced NMR Spectroscopy and First-Principles Calculations. J. Am. Chem. Soc. 2015, 137 (33), 10710-10719.

(57) Perras, F. A.; Wang, Z.; Naik, P.; Slowing, I. I.; Pruski, M. Natural Abundance ${ }^{17} \mathrm{O}$ DNP NMR Provides Precise $\mathrm{O}-\mathrm{H}$ Distances and Insights into the Brønsted Acidity of Heterogeneous Catalysts. Angew. Chem., Int. Ed. 2017, 56 (31), 9165-9169.

(58) Rankin, A. G. M.; Webb, P. B.; Dawson, D. M.; Viger-Gravel, J.; Walder, B. J.; Emsley, L.; Ashbrook, S. E. Determining the Surface Structure of Silicated Alumina Catalysts via Isotopic Enrichment and Dynamic Nuclear Polarization Surface-Enhanced NMR Spectroscopy. J. Phys. Chem. C 2017, 121 (41), 22977-22984.

(59) Mouat, A. R.; George, C.; Kobayashi, T.; Pruski, M.; van Duyne, R. P.; Marks, T. J.; Stair, P. C. Highly Dispersed $\mathrm{SiO}_{x} / \mathrm{Al}_{2} \mathrm{O}$ ${ }_{3}$ Catalysts Illuminate the Reactivity of Isolated Silanol Sites. Angew. Chem., Int. Ed. 2015, 54 (45), 13346-13351.

(60) Sangodkar, R. P.; Smith, B. J.; Gajan, D.; Rossini, A. J.; Roberts, L. R.; Funkhouser, G. P.; Lesage, A.; Emsley, L.; Chmelka, B. F. Influences of Dilute Organic Adsorbates on the Hydration of LowSurface-Area Silicates. J. Am. Chem. Soc. 2015, 137 (25), 8096-8112.

(61) Lafon, O.; Thankamony, A. S. L.; Rosay, M.; Aussenac, F.; Lu, X.; Trébosc, J.; Bout-Roumazeilles, V.; Vezin, H.; Amoureux, J.-P. Indirect and Direct ${ }^{29} \mathrm{Si}$ Dynamic Nuclear Polarization of Dispersed Nanoparticles. Chem. Commun. 2013, 49 (28), 2864-2866.

(62) Yates, J. R.; Pickard, C. J.; Mauri, F. Calculation of NMR Chemical Shifts for Extended Systems Using Ultrasoft Pseudopotentials. Phys. Rev. B: Condens. Matter Mater. Phys. 2007, 76 (2), 024401.

(63) Grimme, S. Semiempirical \{GGA\}-Type Density Functional Constructed with a Long-Range Dispersion Correction. J. Comput. Chem. 2006, 27 (15), 1787-1799.

(64) Giannozzi, P.; Baroni, S.; Bonini, N.; Calandra, M.; Car, R.; Cavazzoni, C.; Ceresoli, D.; Chiarotti, G. L.; Cococcioni, M.; Dabo,
I.; et al. QUANTUM ESPRESSO: A Modular and Open-Source Software Project for Quantum Simulations of Materials. J. Phys.: Condens. Matter 2009, 21 (39), 395502.

(65) Adamo, C.; Barone, V. Toward Reliable Density Functional Methods without Adjustable Parameters: The PBE0Model. J. Chem. Phys. 1999, 110 (13), 6158-6170.

(66) Momma, K.; Izumi, F. VESTA 3 for Three-Dimensional Visualization of Crystal, Volumetric and Morphology Data. J. Appl. Crystallogr. 2011, 44 (6), 1272-1276.

(67) Jakobsen, H. J.; Skibsted, J.; Bildsøe, H.; Nielsen, N. C. MagicAngle Spinning NMR Spectra of Satellite Transitions for Quadrupolar Nuclei in Solids. J. Magn. Reson. 1989, 85 (1), 173-180.

(68) Rocha, J. Direct Observation of Highly Distorted HexaCoordinated Aluminium in Andalusite by Very Fast ${ }^{27} \mathrm{Al}$ MAS NMR. Chem. Commun. 1998, 2489-2490.

(69) Massiot, D. Sensitivity and Lineshape Improvements of MQMAS by Rotor-Synchronized Data Acquisition. J. Magn. Reson., Ser. A 1996, 122 (2), 240-244.

(70) Skibsted, J.; Henderson, E.; Jakobsen, H. J. Characterization of Calcium Aluminate Phases in Cements by Aluminum-27 MAS NMR Spectroscopy. Inorg. Chem. 1993, 32 (6), 1013-1027.

(71) Skibsted, J.; Jakobsen, H. J.; Hall, C. Quantification of Calcium Silicate Phases in Portland Cements by ${ }^{29} \mathrm{Si}$ MAS NMR Spectroscopy. J. Chem. Soc., Faraday Trans. 1995, 91 (24), 4423-4430.

(72) Pickard, C. J.; Mauri, F. All-Electron Magnetic Response with Pseudopotentials: NMR Chemical Shifts. Phys. Rev. B: Condens. Matter Mater. Phys. 2001, 63 (24), 245101.

(73) Pyykkö, P. Spectroscopic Nuclear Quadrupole Moments. Mol. Phys. 2001, 99 (19), 1617-1629.

(74) Lippmaa, E.; Samoson, A.; Magi, M. High-Resolution Aluminum-27 NMR of Aluminosilicates. J. Am. Chem. Soc. 1986, 108 (8), 1730-1735.

(75) Samoson, A. Satellite Transition High-Resolution NMR of Quadrupolar Nuclei in Powders. Chem. Phys. Lett. 1985, 119 (1), 2932.

(76) Smith, W.; Forester, T. R. DL POLY 2.0: A General-Purpose Parallel Molecular Dynamics Simulation Package. J. Mol. Graphics 1996, 14 (3), 136-141.

(77) Galmarini, S.; Bowen, P. Atomistic Simulation of the Adsorption of Calcium and Hydroxyl Ions onto Portlandite Surfaces - Towards Crystal Growth Mechanisms. Cem. Concr. Res. 2016, 81, 16-23.

(78) Mishra, R. K.; Mohamed, A. K.; Geissbühler, D.; Manzano, H.; Jamil, T.; Shahsavari, R.; Kalinichev, A. G.; Galmarini, S.; Tao, L.; Heinz, H.; et al. Cemff: A Force Field Database for Cementitious Materials Including Validations, Applications and Opportunities. Cem. Concr. Res. 2017, 102 (April), 68-89.

(79) Sauvée, C.; Rosay, M.; Casano, G.; Aussenac, F.; Weber, R. T.; Ouari, O.; Tordo, P. Highly Efficient, Water-Soluble Polarizing Agents for Dynamic Nuclear Polarization at High Frequency. Angew. Chem., Int. Ed. 2013, 52 (41), 10858.

(80) Pines, A.; Gibby, M. G.; Waugh, J. S. Proton-enhanced NMR of Dilute Spins in Solids. J. Chem. Phys. 1973, 59 (2), 569-590.

(81) Trebosc, J.; Hu, B.; Amoureux, J. P.; Gan, Z. Through-Space $\mathrm{R}^{3}$-HETCOR Experiments between Spin-1/2 and Half-Integer Quadrupolar Nuclei in Solid-State NMR. J. Magn. Reson. 2007, 186 (2), 220-227.

(82) Gullion, T.; Baker, D. B.; Conradi, M. S. New, Compensated Carr-Purcell Sequences. J. Magn. Reson. 1990, 89 (3), 479-484.

(83) Hanrahan, M. P.; Chen, Y.; Blome-Fernández, R.; Stein, J. L.; Pach, G. F.; Adamson, M. A. S.; Neale, N. R.; Cossairt, B. M.; Vela, J.; Rossini, A. J. Probing the Surface Structure of Semiconductor Nanoparticles by DNP SENS with Dielectric Support Materials. J. Am. Chem. Soc. 2019, 141 (39), 15532-15546.

(84) Damodaran, K.; Rajamohanan, P. R.; Chakrabarty, D.; Racherla, U. S.; Manohar, V.; Fernandez, C.; Amoureux, J. P.; Ganapathy, S. Triple-Quantum Magic Angle Spinning ${ }^{27} \mathrm{Al}$ NMR of Aluminum Hydroxides. J. Am. Chem. Soc. 2002, 124 (13), 32003201. 
(85) Myers, R. J.; Bernal, S. A.; San Nicolas, R.; Provis, J. L. Generalized Structural Description of Calcium-Sodium Aluminosilicate Hydrate Gels: The Cross-Linked Substituted Tobermorite Model. Langmuir 2013, 29 (17), 5294-5306.

(86) Geng, G.; Myers, R. J.; Li, J.; Maboudian, R.; Carraro, C.; Shapiro, D. A.; Monteiro, P. J. M. Aluminum-Induced Dreierketten Chain Cross-Links Increase the Mechanical Properties of Nanocrystalline Calcium Aluminosilicate Hydrate. Sci. Rep. 2017, 7, 44032.

(87) Rawal, A.; Smith, B. J.; Athens, G. L.; Edwards, C. L.; Roberts, L.; Gupta, V.; Chmelka, B. F. Molecular Silicate and Aluminate Species in Anhydrous and Hydrated Cements. J. Am. Chem. Soc. 2010, 132 (21), 7321-7337.

(88) Famy, C.; Brough, A. R.; Taylor, H. F. W. The C-S-H Gel of Portland Cement Mortars: Part I. The Interpretation of EnergyDispersive X-Ray Microanalyses from Scanning Electron Microscopy, with Some Observations on C-S-H, AFm and AFt Phase Compositions. Cem. Concr. Res. 2003, 33 (9), 1389-1398.

(89) Rossen, J. E.; Scrivener, K. L. Optimization of SEM-EDS to Determine the $\mathrm{C}-\mathrm{A}-\mathrm{S}-\mathrm{H}$ Composition in Matured Cement Paste Samples. Mater. Charact. 2017, 123, 294-306.

(90) Puertas, F.; Palacios, M.; Manzano, H.; Dolado, J. S.; Rico, A.; Rodríguez, J. A Model for the C-A-S-H Gel Formed in AlkaliActivated Slag Cements. J. Eur. Ceram. Soc. 2011, 31 (12), 20432056.

(91) Durdziński, P. T.; Ben Haha, M.; Zajac, M.; Scrivener, K. L. Phase Assemblage of Composite Cements. Cem. Concr. Res. 2017, 99, $172-182$.

(92) Avet, F.; Boehm-Courjault, E.; Scrivener, K. Investigation of CA-S-H Composition, Morphology and Density in Limestone Calcined Clay Cement (LC3). Cem. Concr. Res. 2019, 115, 70-79.

(93) Geng, G.; Myers, R. J.; Qomi, M. J. A.; Monteiro, P. J. M. Densification of the Interlayer Spacing Governs the Nanomechanical Properties of Calcium-Silicate-Hydrate. Sci. Rep. 2017, 7 (1), 10986. (94) Hjorth, J.; Skibsted, J.; Jakobsen, H. J. 29Si MAS NMR Studies of Portland Cement Components and Effects of Microsilica on the Hydration Reaction. Cem. Concr. Res. 1988, 18 (5), 789-798.

(95) Kubicki, D. J.; Rossini, A. J.; Purea, A.; Zagdoun, A.; Ouari, O.; Tordo, P.; Engelke, F.; Lesage, A.; Emsley, L. Amplifying Dynamic Nuclear Polarization of Frozen Solutions by Incorporating Dielectric Particles. J. Am. Chem. Soc. 2014, 136 (44), 15711-15718.

(96) Pan, Y.; Gullion, T.; Schaefer, J. Determination of C-N Internuclear Distances by Rotational-Echo Double-Resonance NMR of Solids. J. Magn. Reson. 1990, 90 (2), 330-340.

(97) Fyfe, C. A.; Mueller, K. T.; Grondey, H.; Wong-Moon, K. C. Dipolar Dephasing between Quadrupolar and Spin $-1 / 2$ Nuclei. REDOR and TEDOR NMR Experiments on VPI-5. Chem. Phys. Lett. 1992, 199 (1-2), 198-204.

(98) Chen, Q.; Schmidt-Rohr, K. Measurement of the Local ${ }^{1} \mathrm{H}$ Spin-Diffusion Coefficient in Polymers. Solid State Nucl. Magn. Reson. 2006, 29 (1-3), 142-152.

(99) Walder, B. J.; Prisco, N. A.; Paruzzo, F. M.; Yarava, J. R.; Chmelka, B. F.; Emsley, L. Measurement of Proton Spin Diffusivity in Hydrated Cementitious Solids. J. Phys. Chem. Lett. 2019, 10 (17), 5064-5069.

(100) L'Hôpital, E.; Lothenbach, B.; Le Saout, G.; Kulik, D.; Scrivener, K. Incorporation of Aluminium in Calcium-SilicateHydrates. Cem. Concr. Res. 2015, 75, 91-103.

(101) Dilnesa, B. Z.; Lothenbach, B.; Renaudin, G.; Wichser, A.; Kulik, D. Synthesis and Characterization of Hydrogarnet $\mathrm{Ca}_{3}(\mathrm{Al}$ $\left.{ }_{\mathrm{x}} \mathrm{Fe}_{1-\mathrm{x}}\right)_{2}\left(\mathrm{SiO}_{4}\right)_{\mathrm{y}}(\mathrm{OH})_{4(3-\mathrm{Y})}$. Cem. Concr. Res. 2014, 59, 96-111.

(102) Komarneni, S.; Roy, R.; Roy, D. M.; Fyfe, C. A.; Kennedy, G. J.; Bothner-By, A. A.; Dadok, J.; Chesnick, A. S. ${ }^{27} \mathrm{Al}$ and ${ }^{29} \mathrm{Si}$ Magic Angle Spinning Nuclear Magnetic Resonance Spectroscopy of AlSubstituted Tobermorites. J. Mater. Sci. 1985, 20 (11), 4209-4214.

(103) Lippmaa, E.; Maegi, M.; Samoson, A.; Tarmak, M.; Engelhardt, G. Investigation of the Structure of Zeolites by SolidState High-Resolution Silicon-29 NMR Spectroscopy. J. Am. Chem. Soc. 1981, 103 (17), 4992-4996.
(104) Lechert, H. G.; et al. High Resolution Solid State NMR of Silicates and Zeolites. John Wiley \& Sons, Chichester, 1987; Berichte der Bunsengesellschaft für Phys. Chemie 1988, 92 (9), 1059-1059, DOI: $10.1002 /$ bbpc. 198800267.

(105) Baltisberger, J. H.; Florian, P.; Keeler, E. G.; Phyo, P. A.; Sanders, K. J.; Grandinetti, P. J. Modifier Cation Effects on ${ }^{29} \mathrm{Si}$ Nuclear Shielding Anisotropies in Silicate Glasses. J. Magn. Reson. 2016, 268, 95-106.

(106) Magi, M.; Lippmaa, E.; Samoson, A.; Engelhardt, G.; Grimmer, A. R. Solid-State High-Resolution Silicon-29 Chemical Shifts in Silicates. J. Phys. Chem. 1984, 88 (8), 1518-1522.

(107) Thomas, J. J.; Chen, J. J.; Jennings, H. M.; Neumann, D. A. $\mathrm{Ca}-\mathrm{OH}$ Bonding in the C-S-H Gel Phase of Tricalcium Silicate and White Portland Cement Pastes Measured by Inelastic Neutron Scattering. Chem. Mater. 2003, 15 (20), 3813-3817.

(108) Hou, D.; Li, Z.; Zhao, T. Reactive Force Field Simulation on Polymerization and Hydrolytic Reactions in Calcium Aluminate Silicate Hydrate (C-A-S-H) Gel: Structure, Dynamics and Mechanical Properties. RSC Adv. 2015, 5 (1), 448-461.

(109) Renaudin, G.; Russias, J.; Leroux, F.; Frizon, F.; Cau-ditCoumes, C. Structural Characterization of C-S-H and C-A-S-H Samples-Part I: Long-Range Order Investigated by Rietveld Analyses. J. Solid State Chem. 2009, 182, 3312-3319.

(110) Roosz, C.; Gaboreau, S.; Grangeon, S.; Prêt, D.; Montouillout, V.; Maubec, N.; Ory, S.; Blanc, P.; Vieillard, P.; Henocq, P.; et al. Distribution of Water in Synthetic Calcium Silicate Hydrates. Langmuir 2016, 32 (27), 6794-6805. 